Article

\title{
Regional Parameter Estimation of the SWAT Model: Methodology and Application to River Basins in the Peruvian Pacific Drainage
}

\author{
Flavio Alexander Asurza-Véliz * (D) and Waldo Sven Lavado-Casimiro (D) \\ Dirección de Hidrología, Servicio Nacional de Meteorología e Hidrología del Perú (SENAMHI), \\ Lima 15072, Peru; wlavado@senamhi.gob.pe \\ * Correspondence: falexav@gmail.com
}

Received: 15 September 2020; Accepted: 6 November 2020; Published: 16 November 2020

check for updates

\begin{abstract}
This study presents a methodology for the regional parameters estimation of the SWAT (Soil and Water Assessment Tool) model, with the objective of estimating daily flow series in the Pacific drainage under the context of limited hydrological data availability. This methodology has been designed to obtain the model parameters from a limited number of basins (14) to finally regionalize them to basins without hydrological data based on physical-climatic characteristics. In addition, the bootstrapping method was selected to estimate the uncertainty associated with the parameters set selection in the regionalization process. In general, the regionalized parameters reduce the initial underestimation which is reflected in a better quantification of daily flows, and improve the low flows performance. Furthermore, the results show that the SWAT model correctly represents the water balance and seasonality of the hydrological cycle main components. However, the model does not correctly quantify the high flows rates during wet periods. These findings provide supporting information for studies of water balance and water management on the Peruvian Pacific drainage. The approach and methods developed can be replicated in any other region of Peru.
\end{abstract}

Keywords: regional parameters; SWAT; daily flows; Peruvian Pacific drainage

\section{Introduction}

The basins that drain into the Pacific Ocean of Peru are characterized by small basins with bare and steep slopes that favor erosion and flooding during intense rainfall events. Rainfall is more abundant along the north coast and decreases towards the south, where conditions are extremely arid [1]. The Pacific drainage represents $22 \%$ of the Peruvian territory [2], where more than $50 \%$ of the Peruvian population is established and has $2 \%$ of all the fresh water available in Peru [3], generating frequent conflicts between multiple water users regarding its allocation and accessibility. Currently, $73 \%$ of the population lives in urban environments, and it is expected that it (as well as their living standards) will increase by 2050 to approximately 40 million [4]. Therefore, domestic and agricultural water use is likely to increase rapidly, even more so in a country where much of the current agricultural production depends on irrigation and consumes approximately $85 \%$ of surface water [5]. Despite the importance of knowing water availability in Peru, previous studies [6-8] have shown evidence of the limited hydrological data availability in the Pacific drainage (Pd).

The evaluation of the water availability of a basin is generally performed through hydrological models. Rainfall-runoff modeling is an important area of research for the global scientific community that addresses the hydrology. A simple reason for this is that quantitative or qualitative flow information is vital for many practical applications, such as water allocation, long-term planning, watershed management operations, flood forecasting, optimization of the hydroelectric power 
production, and the hydraulic structures design. Although hydrological models can provide information on the rainfall-runoff mechanism, they remain abstractions of a real system, and it cannot be assumed that any of them generate accurate information for specific hydrographic basins and hydrological conditions [9]. Hydrological modeling requires calibration, which to a certain extent offers a reliability of the the measured flow rates simulations, especially in the context of (1) lack of hydrological process understanding, (2) possibly too simplistic representations of the process (abstractions), (3) the spatio-temporal discretization of highly heterogeneous rainfall-runoff processes, and (4) the impossibility of measuring all the model parameters required in the application scale [10]. In addition, in regions with little measured hydrological data, such as Peru, the set of parameters transfer of a calibrated model from one or more basins to a basin without hydrological data is a valid tool to quantify the hydrological processes that occur within them. This process of transfer is known as regionalization [11].

Flow regionalization is a challenging task in the hydrology science [12-14]. First, due to the absence of flow data required for the model calibration, and second, studies evaluating regionalization methods usually produce different results [12]. Despite this research momentum, there is still no single accepted approach to predict flows in regions with no hydrological data $[15,16]$. A large number of hydrological models regionalization methods have been proposed in the literature. All of them are based on the concept that information on the hydrological response can be transferred between hydrographic basins that can be assumed to be hydrologically similar, generally based on the knowledge of their relevant physical properties. The differences between the approaches are found in the type of information that is transferred, the method used and the watershed properties used to quantify the similarity. There are at least three common regionalization approaches: the regression-based approach, the spatial proximity approach, and the physical similarity approach. Comparative studies have been conducted in small and large data sets, in multiple hydrological models and with many variants [12,17-21]. The authors of [16] conducted an exhaustive review of regionalization studies during the last decade. The most notable studies have had some divergent results, which are part of the reason why more conclusive evidence is required [12,22]. Most studies use simple hydrological models with few parameters to preserve a high level of independence and a good correlation between the parameters and the basins descriptors. For hydrological models with small parameter spaces and low parameter interdependence, equifinality is often not a problem. However, if the hydrological model has the opposite attributes, many optimal parameter sets can be found during calibration. The current modeling philosophy requires that the models be described transparently and that the uncertainty analysis be performed routinely as part of the modeling work. This analysis is essential to evaluate the calibrated model strength [23,24].

The SWAT (Soil and Water Assessment Tools) model [25] has shown its strengths in the aspects detailed above. It has been used both to quantify uncertainty and evaluate regionalization methods [24,26-30]. In addition, the SWAT model is open source with a large and growing number of applications in hydrological modeling applied in studies ranging from basin scale to continental scales. There are few published studies related to SWAT in South America for flow estimation purposes [31-35]. In Peru, its use is not yet widespread [36,37], although hydrological models ranging from aggregated to semidistributed have been used in recent years. The references show that the models in Peru have been developed mainly to evaluate the impact of climate change on hydrology [38-41], the evaluation of satellite rainfall products for hydrology purposes [42-46] and there is only one study that performs a parameters regionalization at the scale of the Pd using a lumped hydrological model [8]. During recent years, some hydrological studies have been developed on the Peruvian Pd: [47] documented and analyzed the previous hydrological and physical conditions throughout the study area (54 hydrographic basins) from the 1920 to the 1960s. The authors of [3] evaluated the water supply and demand in the main basins where water management is prioritized. They estimated the total annual volume of fresh water available throughout the Pd from the 1970s to 2010. The authors of [6] analyzed mean conditions and flow variability from 1969 to 2004. The authors 
of [48] identified the annual runoff for some hydrographic basins with low water balance disparities or with quasi-natural conditions on an interannual scale from 1970 to 2008. Finally, [8] quantified and analyzed the flow variability and seasonality in natural regime in $49 \mathrm{Pd}$ basins by applying a parameters regionalization methodology from conceptual models. There have been numerous efforts to evaluate and quantify the water resources in the Pd during recent years; however, there are still no regional studies with the purpose of estimating natural series of daily flows.

In this context, the objective of this work is to use SWAT to build a hydrological model for the $\mathrm{Pd}$ at subbasin level and at a daily time step. The key objectives of this work are (1) to present for the first time a regionalization parameters methodology based on a physical basis model, (2) to estimate water availability in the period 1981-2016 under a context of data scarcity, and (3) to quantify the uncertainty associated with the parameter regionalization process. In particular, components such as blue water (water yield plus deep aquifer recharge), green water flow (real evapotranspiration) and green water storage (soil moisture) are quantified. The estimates of the model at subbasin level are added to basin levels to compare it with previous studies and to support the obtained results. This article is organized as follows: Section 3 briefly describes the structure of the SWAT model and explains the proposed methodology. The calibration results, the estimated regional flow statistical performance and the uncertainty analysis are discussed in Sections 4 and 5. Finally, Section 6 provides the summary and conclusions of this study.

\section{Study Area}

The Pacific drainage (Pd) has an approximate area of $278,482 \mathrm{~km}^{2}$. The study region includes 52 main hydrographic basins with altitudinal variations ranging from 0 to approximately 6500 masl (Figure 1). These basins have bare and steep slopes and generally drain west from the high Andes to the Pacific Ocean. In addition, during heavy rainfall events, a high potential for increased maximum flows, floods and erosion prevails in the Pd [6,48].

Under normal conditions, this region is influenced by the South Pacific Anticyclone in combination with the Humboldt Current, which produces dry and stable conditions in the western central Andes. Additionally, this region exhibits greater seasonal and interannual rainfall variability than the other two main hydrological regions of Peru: the Titicaca and Amazon drainages [6], mainly caused by the influence of the El Niño Southern Oscillation (ENSO). ENSO generates impacts on the regional climate worldwide, particularly on the Pacific coast, and these impacts are reflected in the strong El Niño years, which has a direct influence on rainfall increase (decrease) in the northern (southern) zone [7,49-51], also causing large economic losses [52].

The study area presents arid and semiarid conditions and, therefore, is prone to threats of water scarcity for different sectors. The water demand for economical activities (agriculture, mining, industry and livestock) and domestic use represent approximately $87 \%$ of the total national consumption. Only agriculture represents the greatest consumptive use $(86 \%)$, whose availability depends mainly on the irrigation systems located in the basins valleys. In addition to the threat of water scarcity, Pd is prone to devastating floods [3]. 


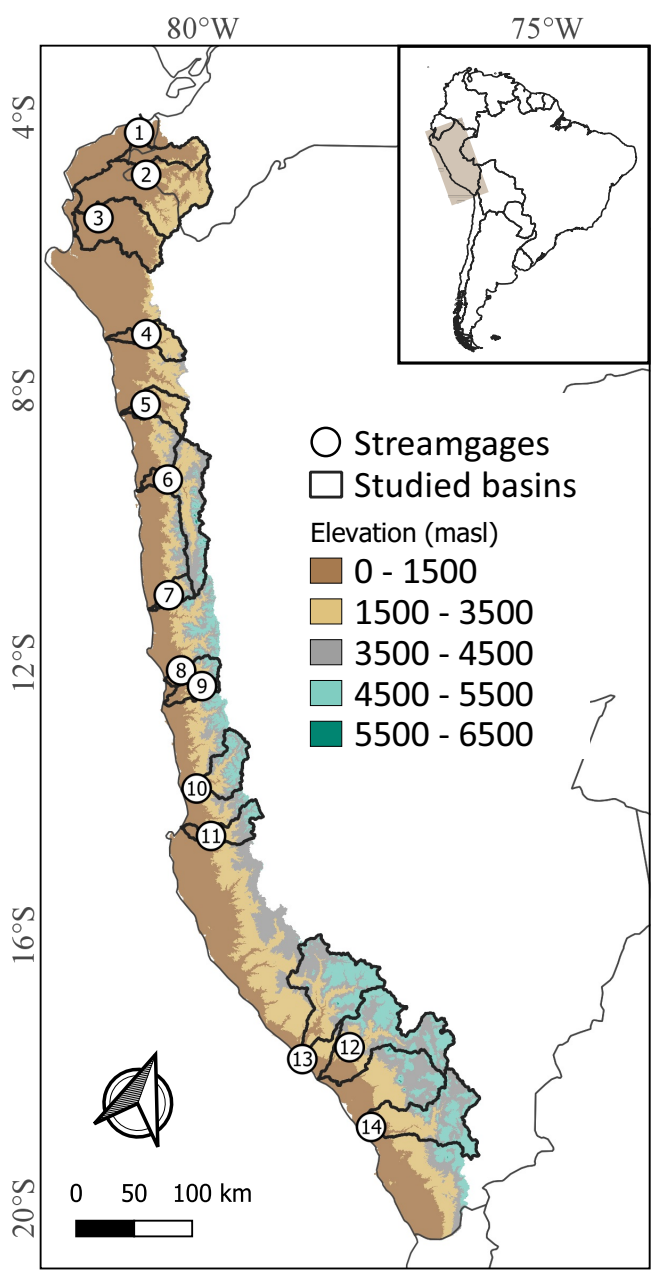

Figure 1. Spatial distribution of the 14 studied basins in the Pacific drainage and topography from the Hydrological data and maps base on SHuttle Elevation Derivatives at multiple Scales (HydroSHEDS, $450 \mathrm{~m}$ ) digital elevation model. Enumerated streamgages listed in Table 1. 
Table 1. Studied Basins along Pacific drainage. Values calculated upstream of the streamgage for basin area (Ab), mean annual rainfall (Rm), mean annual flow (Qm) and runoff coefficient (Rc). Soil, and land cover attributes (FRST $=$ Forest, PAST $=$ Pasture, BARR = Barren soil).

\begin{tabular}{|c|c|c|c|c|c|c|c|c|c|c|c|c|c|c|}
\hline \multirow{2}{*}{$n^{o}$} & \multirow{2}{*}{ River Basin } & \multirow{2}{*}{$\begin{array}{l}\text { Streamgage } \\
\text { (Data Period) }\end{array}$} & \multirow{2}{*}{ Calibration Period } & \multirow{2}{*}{$\begin{array}{c}\mathrm{Ab} \\
\left(\mathrm{km}^{2}\right)\end{array}$} & \multirow{2}{*}{$\begin{array}{c}\mathrm{Rm} \\
(\mathrm{mm})\end{array}$} & \multirow{2}{*}{$\underset{(\mathrm{mm})}{\mathrm{Qm}}$} & \multirow{2}{*}{$\begin{array}{c}\mathrm{Rc} \\
(\mathrm{Qm} / \mathrm{Rm})\end{array}$} & \multicolumn{3}{|c|}{ Soil Composition } & \multicolumn{4}{|c|}{ Land Cover Type } \\
\hline & & & & & & & & Clay (\%) & Silt (\%) & Sand $(\%)$ & PAST (\%) & FRST (\%) & BARR (\%) & Other $(\%)$ \\
\hline 1 & Tumbes & $\begin{array}{c}\text { El Tigre } \\
(1981-2016)\end{array}$ & January 1981-December 2003 & 5007 & 861 & 746 & 0.87 & 34 & 35 & 31 & 0 & 99 & 0 & 0.71 \\
\hline 2 & Chira & $\begin{array}{c}\text { El Ciruelo } \\
(1981-2016)\end{array}$ & January 1981-December 2003 & 7050 & 796 & 476 & 0.60 & 35 & 34 & 31 & 0 & 88 & 12 & 0 \\
\hline 3 & Piura & $\begin{array}{c}\text { Puente Sánchez Cerro } \\
(1997-2016)\end{array}$ & January 1990-December 2008 & 7575 & 510 & 180 & 0.35 & 28 & 23 & 49 & 0 & 63 & 37 & 0 \\
\hline 4 & $\begin{array}{l}\text { Chancay } \\
\text { Lambayeque }\end{array}$ & $\begin{array}{l}\text { Racarrumi } \\
(1981-2016)\end{array}$ & January 1981-December 2003 & 2371 & 768 & 460 & 0.60 & 27 & 35 & 38 & 0 & 81 & 19 & 0 \\
\hline 5 & Chicama & $\begin{array}{c}\text { Salinar } \\
(1981-2016)\end{array}$ & January 1981-December 2003 & 3671 & 477 & 206 & 0.43 & 23 & 31 & 46 & 0 & 81 & 19 & 0 \\
\hline 6 & Santa & $\begin{array}{l}\text { Condorcerro } \\
(1981-2016)\end{array}$ & January 1981-December 2003 & 10,404 & 576 & 413 & 0.72 & 24 & 35 & 41 & 48 & 45 & 0 & 7 \\
\hline 7 & Fortaleza & $\begin{array}{c}\text { Malvados } \\
(2000-2016)\end{array}$ & January 1997-December 2009 & 1317 & 304 & 134 & 0.44 & 30 & 36 & 34 & 0 & 78 & 22 & 0 \\
\hline 8 & $\begin{array}{l}\text { Chancay } \\
\text { Huaral }\end{array}$ & $\begin{array}{l}\text { Santo Domingo } \\
\text { (1994-2016) }\end{array}$ & January 1991-December 2007 & 1851 & 429 & 273 & 0.64 & 27 & 37 & 37 & 27 & 54 & 19 & 0 \\
\hline 9 & Chillón & $\begin{array}{c}\text { Obrajillo } \\
(1997-2016)\end{array}$ & January 1994-December 2008 & 486 & 705 & 333 & 0.47 & 24 & 37 & 39 & 40 & 14 & 46 & 0 \\
\hline 10 & Cañete & $\begin{array}{c}\text { Socsi } \\
(1981-2016)\end{array}$ & January 1981-December 2003 & 5789 & 385 & 281 & 0.73 & 25 & 37 & 38 & 54 & 42 & 4 & 0 \\
\hline 11 & Pisco & $\begin{array}{c}\text { Letrayoc } \\
(1981-2016)\end{array}$ & January 1981-December 2003 & 3088 & 494 & 247 & 0.50 & 24 & 37 & 40 & 61 & 6 & 33 & 0 \\
\hline 12 & Camaná & $\begin{array}{c}\text { Huatiapa } \\
(1998-2016)\end{array}$ & January 1994-December 2008 & 12,845 & 458 & 184 & 0.40 & 18 & 37 & 46 & 47 & 17 & 36 & 0 \\
\hline 13 & Ocoña & $\begin{array}{l}\text { Puente Ocoña } \\
\text { (2006-2016) }\end{array}$ & January 2004-December 2011 & 15,972 & 367 & 170 & 0.46 & 17 & 37 & 47 & 36 & 26 & 38 & 0.02 \\
\hline 14 & Tambo & $\begin{array}{l}\text { Puente Santa Rosa } \\
\quad(1981-2016)\end{array}$ & January 1981-December 2003 & 12,891 & 254 & 73 & 0.29 & 18 & 38 & 44 & 18 & 4 & 78 & 0 \\
\hline
\end{tabular}




\section{Materials and Methods}

The general scheme of the proposed methodology is shown in Figure 2. The first part consisted of the soil gridded data recompilation and climate data. Then, the hydrological modeling process was carried out through a parameter sensitivity analysis process and calibration, while the hydrological similarity was defined through a physical similarity approach. Finally, the parameter transfer process determined the regional parameters used to estimate the series of daily flow in the entire Pd. More detail on the explained processes is shown below.

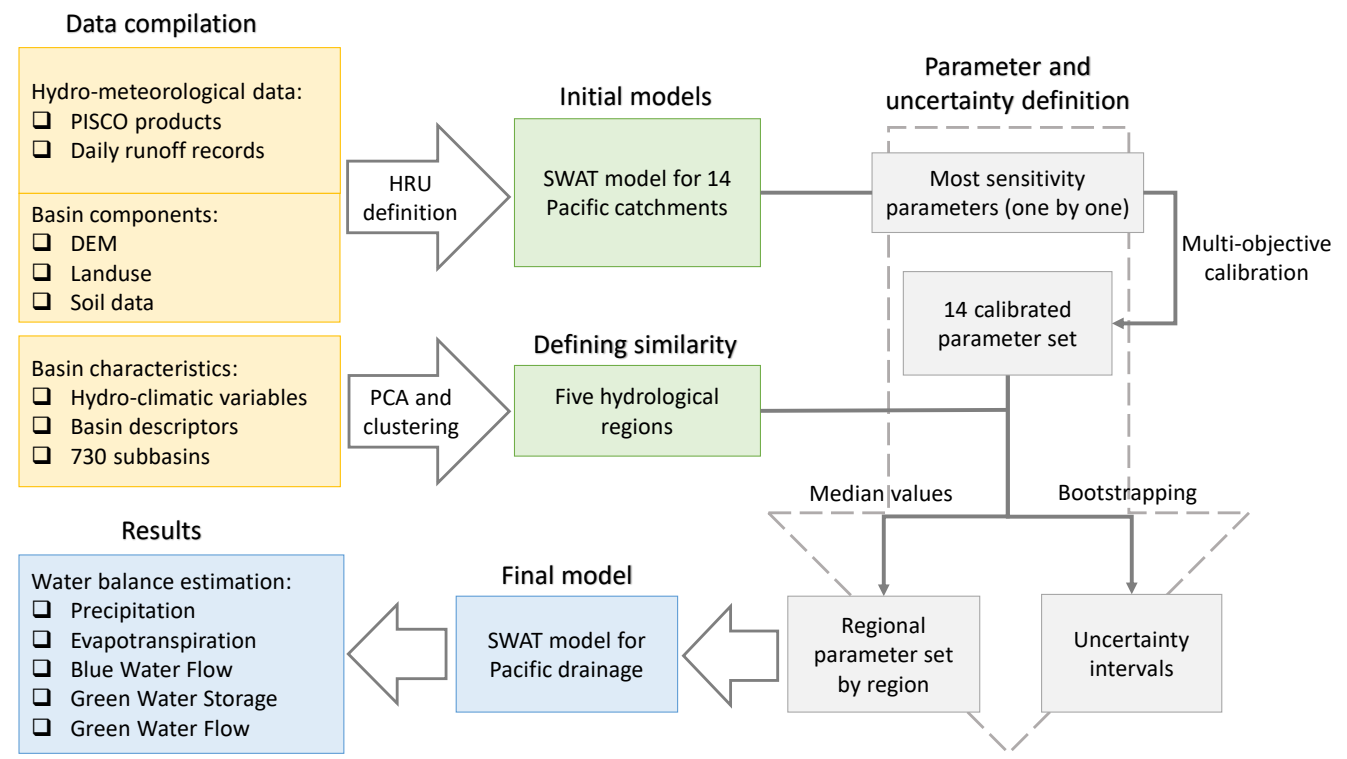

Figure 2. The conceptual framework of the study: water balance model flowchart of Pacific drainage subbasins.

\subsection{Hydrological Modelling Platform}

Among the semi-distributed hydrological models, the SWAT model has been developed for the runoff estimation in areas without hydrological measurements [25,53]. SWAT is a physically based model that operates on a continuous (daily) time scale. In addition, it subdivides a basin into subbasins, which are connected by a flow network. The subbasins can be divided into hydrological response units (HRUs), which are unique combinations of land use, soil type and slope. The hydrological simulation is based on the water balance equation and is divided into two main components: the terrestrial phase, which simulates the amount of water, sediments, nutrients and pesticide loads in the main channel of each subbasin, and the routing phase, which simulates the movement of water, sediments and nutrients through the channel network of the basin to the outlet [54].

The climatic variables of entry to the SWAT consist of rainfall, maximum and minimum air temperature, solar radiation, wind speed and relative humidity. Optionally, the operations of reservoir management, lakes, transfers and crop management can also be considered in the model scheme. Further details of the SWAT can be found in the theoretical documentation (http:/ / swatmodel.tamu. edu) and in [25].

\subsection{Model Input}

The model was configured based on freely downloadable data. In the case of geographic data, ref. $[55,56]$ have shown that the results of the SWAT model are affected by the spatial resolution of the 
aforementioned data. Therefore, the resolutions considered below were selected based on the data availability for the Pd and the size of subbasins to be delimited (as discussed later in this section).

- The rainfall and temperature data were obtained from the product PISCO (Peruvian Interpolated data of Senamhi's Climatological and Hydrological Observations). The daily rainfall database corresponded to version 2.1 [57], while the daily temperature database (maximum and minimum) was version 1.1 [58]. Both products are available from January 1981 to December 2016 and have a spatial resolution of 0.1 degree $(\sim 10 \mathrm{~km})$. These databases are available on the IRI Climate Data Library website (http:/ /iridl.ldeo.columbia.edu/SOURCES/.SENAMHI/.HSR/.PISCO/index. html?Set-Language=es).

- $\quad$ The 450-m digital elevation model (DEM) was obtained from HydroSHEDS (Hydrological data and maps base on SHuttle Elevation Derivatives at multiple Scales). This product is based on high-resolution elevation data obtained from SRTM (Shuttle Radar Topography Mission) [59].

- $\quad$ The 300-m land-use map used corresponds to 2015 and was obtained from the ESA CCI-LC (European Space Agency and Climate Change Initiative-Land Cover) project [60].

- $\quad$ The $8 \mathrm{~km}$ soil type map was obtained from FAO-UNESCO. The map for Volume IV South America [61] was taken, which gridded data was released in 2006.

Flow data from 14 streamgages were obtained from the National Service of Meteorology and Hydrology of Peru (SENAMHI). The observed daily flow series meet the following requirements: (1) have at least 10 years of record in the period 1981-2016, (2) the series are only minimally affected by extractions, transfer, and dams; (3) the flow series corresponds to the main basins and covers much of the total area of the Pd.

\subsection{Model Setup}

The model was implemented in SWAT 2012 using the QSWAT interface [62]. For the subbasins delimitation, two criteria were taken: (1) the burn-in option was used from predefined rivers to improve the delimitation in flat areas [63], and (2) an area threshold was established to be $200 \mathrm{~km}^{2}$. In addition, the HRUs were defined based on land use, soil type and dominant slope. This configuration was considered appropriate according to the computational resources available for hydrological modeling at the drainage scale.

The potential evapotranspiration was estimated by the Hargreaves-Samani method [64] due to the limited and scarce availability of observed data on relative humidity, wind speed and solar radiation. In addition, this method has shown good results comparable with Priestley-Taylor [65] and Penman-Monteith [66] (methods also available in SWAT) in semiarid zones [67]. The model did not include data on reservoirs operation, lakes or any other hydraulic influence.

\subsection{Model Calibration}

The SWAT input parameters are based on real processes and must be kept within a range of realistic uncertainty, so the first step in the calibration process was determinate the most sensitive parameters of the hydrological model [68]. In this way, from a sensitivity analysis for each parameter (one-at-a-time), the search ranges of each parameter were identified (ranges that respected the physical meaning of each one) so that the SWAT model is able to quantify the flow contributed by surface runoff and baseflow. In addition, as recommended by [69], it was considered to calibrate the model with the fewest possible parameters.

\subsubsection{Evaluation Metrics}

The calibration process considered a warm-up period of 3 years, and the statistical performance was evaluated based on the Kling-Gupta efficiency criterion (KGE) and the logarithmic Nash index $(\log N S E)$. 
- Overall performance: KGE is a comprehensive metric, a weighted average of the Pearson product-moment correlation coefficient $(r)$, the ratio between the mean of the simulated values and the mean of the observed ones $(\beta)$, and variability ratio $(\gamma)$, which is computed using the standard deviation of simulated and observed (Equation (1)). Kling-Gupta efficiencies range from -Infinity to 1 . The closer to 1 , the more precise the model is.

$$
K G E=\sqrt{(r-1)^{2}+(\beta-1)^{2}+(\gamma-1)^{2}}
$$

- Low flows: By taking the $\log$ of simulated $\left(\log \mathrm{S}_{i}\right)$ and observed $\left(\log \mathrm{O}_{i}\right)$ before calculating the NSE, the influence of (missing) peak flows is reduced and more emphasis is placed on the base flow (the criticism of the standard NSE is that it is overly sensitive to the magnitude and timing of peak flows (Equation (2)).

$$
\log N S E=1-\frac{\sum_{i=1}^{n}\left(\log O_{i}-\log S_{i}\right)^{2}}{\sum_{i=1}^{n}\left(\log O_{i}-\log \bar{O}\right)^{2}}
$$

Maximizing the KGE and logNSE, the performance of the hydrological modeling was optimized from a multi-objective perspective using the correlation, variability and bias criteria [70] and the performance in the representation of low flow rates. These statistics have been used in previous studies, resulting in good calibration and good performance in hydrological modeling [71-73].

The calibration and validation of the simulated and observed flows performance was carried out in 14 basins with daily flow data availability. The calibration period indicated in Table 1 was used to obtain the calibrated parameters. Then, we validate the performance of the model in two periods: the subsequent period to the calibration period until December 2016 and the entire period 1981-2016. The goodness of fit parameters were estimated through the R package "hydroGOF" [74].

\subsubsection{Multiobjective Calibration Algorithm}

The optimal parameters were derived from the Elitist Non-dominated Sorting Genetic Algorithm II (NSGA-II) multi-objective calibration algorithm, whose application has provided excellent results in hydrological modeling using SWAT and has been shown to be more efficient than the Monte Carlo method to reduce optimized parameters uncertainty [75,76]. Unlike single objective genetic algorithms, NSGA-II assigns fitness by Pareto ranking (nondomination) and crowding distance to the combined parent and child populations. A solution (or individual) is nondominated if it performs better in at least one objective functions and as well in all the other objective functions. The individual is then ranked according to the number of solutions that dominates it. Crowding distance is the average distance between an individual and its nearest neighbors in the search space. With the objective functions as minimization problems, individuals that are dominated by fewer solutions (i.e., has a lower rank) are given a better fitness than the dominated ones. In cases where the solutions have the same nondomination rank, the individual with larger crowding distance is preferred, thus ensuring diverse and well-spread population. The new parent population is chosen from the combined parent and child population based on the individuals' fitness or rank, thus the elitist selection.

NSGA-II nondominated sorting algorithm has a computational complexity $O\left(M N^{2}\right)$, where $M$ is the number of objectives and $N$ is the size of a population $P$. For each solution two parameters are calculated in the algorithm: (1) the domination count $n_{i}$ which is the number of solutions that dominate the solution $i$ and (2) a set of solutions $S_{i}$ that the solution $i$ dominates. The solutions of the first non-dominated front are identified in Steps 1 to 3 of the algorithm and the solutions in higher fronts are searched in Steps 4 to 6. The algorithm is as follows:

- $\quad$ Step 1: For each $i \in P$, set $n_{i}=0$ and $S_{i}=\varnothing$.

- Step 2: For all $j \neq i$ and $j \in P$, if i dominates $j$, Add $j$ to the set of solutions dominated by $i: S_{i}=S_{i}$ $\mathrm{U}$ j. Otherwise, increment the domination count of $i: n_{i}=n_{i}+1$. 
- $\quad$ Step 3: If $n_{i}=0$, keep $i$ in the first non-dominated front $P_{1}$ and set the front counter $k=1$.

- $\quad$ Step 4: While $P_{k} \neq \varnothing$, initialize $Q=\varnothing$ for storing the next non-dominated solutions.

- Step 5: For each $i \in P_{k}$ and for each $j \in S_{i}$, update $n_{j}=n_{j}-1$. If $n_{j}=0, j$ belongs to the next front and update $Q=Q \mathrm{U} j$.

- $\quad$ Step 6: Set $k=k+1$ and $P_{k}=Q$, go to Step 4 .

Further details of NSGA-II can be found in [77]. The calibration algorithm was implemented through the R library "nsga2R" [78], setting KGE and logNSE as objective functions.

\subsection{Regionalization Using the Physical Similarity Approach}

The similarity approach consists of transferring hydrological information from donor basins (with flow data) that are similar to basins without flow data based on basin descriptors. For this, the climatic and physiographic variables of [12] are detailed in Table 2.

Table 2. Distributions of hydro-climatic characteristics and descriptors of the 730 Peruvian Pacific subbasins used for clustering.

\begin{tabular}{|c|c|c|c|c|c|c|}
\hline Basin Characteristics & $\begin{array}{l}\text { Notation } \\
\text { (Unit) }\end{array}$ & Min & 25th Percentile & Median & 75th Percentile & Max \\
\hline \multicolumn{7}{|l|}{ Hydro-Climatic Characteristics } \\
\hline Mean annual potential evapotranspiration & $\mathrm{Em}(\mathrm{mm} /$ year $)$ & 1064 & 1326 & 1511 & 1679 & 2768 \\
\hline Mean annual flow & Qm (mm/year) & 0 & 0.1 & 14 & 108 & 588 \\
\hline Runoff coefficient & Qm/Rm (-) & 0 & 0.01 & 0.08 & 0.28 & 0.61 \\
\hline Basin area & $\mathrm{Ab}\left(\mathrm{km}^{2}\right)$ & 0.56 & 222 & 321 & 495 & 1735 \\
\hline Basin slope & $\mathrm{Sb}(-)$ & 0 & 0.08 & 0.17 & 0.26 & 0.55 \\
\hline Mean basin altitude & $\mathrm{Zb}(\mathrm{m})$ & 0 & 536 & 1753 & 3460 & 4868 \\
\hline Drainage density & dc $(-)$ & 0.001 & 0.035 & 0.057 & 0.09 & 0.75 \\
\hline Fraction of forest cover & fc $(-)$ & 0 & 0.06 & 0.26 & 0.56 & 0.99 \\
\hline
\end{tabular}

\subsubsection{Clustering Dataset}

There are a variety of cluster analysis techniques available to group basins into groups with similar characteristics. However, not one of them has been proven to be better than the others [79]. To group the Pd subbasins into regions assumed to be hydrologically homogeneous, Ward's hierarchical classification method [80] and principal component analysis (PCA) were used. The Ward method minimizes the total internal variance of each identified cluster, while the PCA reduces the dimensionality from a large number of interrelated variables while retaining most of the variation of the data used [81]. The variables in Table 2 were estimated from the input and the output data obtained in the first run of the SWAT model (without calibration) for a total of $730 \mathrm{Pd}$ subbasins. The subbasins were delimited according to the criteria mentioned in Section 3.3.

The estimated clusters or regions were validated by Dunn and Silhouette indices, which are mainly used to choose the optimal number of clusters without the need for additional external information [82-84]. Dunn Index represents the ratio of the smallest distance between observations not in the same cluster to the largest intra-cluster distance. If the data set contains compact and well-separated clusters, the largest distance is expected to be small and the smallest one is expected to be large. Silhouette index defines compactness based on the pairwise distances between all elements in the cluster, and separation based on pairwise distances between all points in the cluster and all points in the closest other cluster. In both cases, the index should be maximized.

This validation procedure was carried out using the R library "clValid" [85]. 


\subsubsection{Parameter Transfer Scheme}

The calibrated parameters from a limited number of basins (14) were used to represent the hydrological characteristics in each region. To increase the amount of calibrated parameters set for each basin, an strategy of considering the default (uncalibrated) SWAT parameters sets was chosen. For example, in the case of basins with streamgages not located at the point of exit of the basin, the resulting calibrated SWAT model would have two parameters set: parameters set from the subbasins upstream of the streamgage and the default parameters set from subbasins downstream of the streamgage.

The subbasins belonging to the same region were considered similar. In this context, unlike the approach presented in [86], the calibrated parameters set located in each region were grouped to obtain the regional parameters through the median. From them, the evaluation was performed by comparing the simulated and observed daily flows for the period 1981-2016 in the 14 studied basins.

\subsection{Uncertainty Analysis}

Under the assumption of equifinality, two basins belonging to the same region could have parameters set that are not correlated, which could clearly be problematic for regionalization studies. In this case, the model parameters are only correlated with basin attributes, which undermines the basic hypothesis of methods based on similarity [23].

In this study, the uncertainty associated with the parameters set selection process for regional hydrological modeling was analyzed. A stochastic process was used to quantify uncertainty in simulated daily flow series based on the findings of [23], in which the parameters set available for each region were resampled by bootstrapping [87]. The resampling was repeated 500 times, and then confidence intervals of the bootstrapping distribution were taken at the 95th percentile (lower limit: 0.025 quantile and upper limit: 0.975 quantile) to define the uncertainty bands (UB). The quantification of the uncertainty degree was evaluated based on the coverage ratio $(C R)$ and average width index $(A W I)$, which represent the amount of observed data that are contained in the UB and its width respectively [88-90].

The $C R$ quantifies the statistical reliability of the derived UB to contain the value of the observed flow $\left(Q_{O, T}\right)$ (Equation (3)).

$$
\begin{gathered}
C=\left\{\begin{array}{c}
1 \text { if } Q_{O, T}>Q_{L, T} \text { and } Q_{O, T}<Q_{U, T} \\
0 \text { if } Q_{O, T}>Q_{L, T} \mid Q_{O, T}<Q_{U, T}
\end{array}\right\} \\
C R=\frac{1}{T} \sum_{i=1}^{T} C
\end{gathered}
$$

where $C$ is equal to 1 in the time step if the observed flow rate $\left(Q_{O, T}\right)$ is greater than the lower limit of UB $\left(Q_{U, T}\right)$ and less than the upper limit of UB $\left(Q_{U, T}\right)$; and 0 otherwise. The resulting series $(C)$ is added and divided by the number of time steps $(T)$ (that is, the total number of observed flow to calculate the $C R$ ). The $C R$ provides a proportional measure that goes from 0 to 1 , where 1 represents a perfect value (the uncertainty intervals contain all the values of the observed flow) and 0 indicates that the uncertainty intervals do not have reliability to contain these values.

The $A W I$ is a measure of the sharpness of the UB and quantifies the capacity of the UB to capture the system natural variability and the expected simulations of the model. The $A W I$ is a measure of overlap between the width of the 95th percentiles of the observed flow duration curve (called $A W_{\text {clim }}$ ) and the average width $(A W)$ of the uncertainty intervals, which is calculated as the average of the absolute difference between the upper and lower UB in all time steps. This is calculated as shown in Equation (4):

$$
A W I=1-\frac{A W}{A W_{\text {clim }}}
$$


where $A W$ is the average width index of the UB time series, and $A W_{\text {clim }}$ is the absolute difference (width) of the quantiles 0.025 and 0.975 of the observed flow duration curve. An AWI value greater than 0 indicates that the derived UB reduces the uncertainty of the model output compared to the climatology natural variability, represented by the 95th percentile of the observed flow duration curve.

\section{Results}

\subsection{Defining Similarity by Clustering}

Prior to clustering, PCA was used to reduce the dimensionality of the 11 variables shown in Table 2.

Table 3 shows that the first 5 components explain approximately $90 \%$ of the accumulated variance, and their eigenvalues are greater than 0.8. The mean annual rainfall $(\mathrm{Rm})$, mean annual flow $(\mathrm{Qm})$ and runoff coefficient $(\mathrm{Rc}$ ) show a high correlation with the first component. Latitude (lat), longitude (long), mean basin altitude $(\mathrm{Zb})$ and mean annual potential evapotranspiration $(\mathrm{Em})$ are better correlated with the second component, while basin slope $(\mathrm{Sb})$ and fraction of forest cover $(\mathrm{fc})$ are better correlated with the third component. The basin area $(\mathrm{Ab})$ and drainage density $(\mathrm{dc})$ variables have a high correlation with the fourth and fifth components; however, the latter has a little contribution to the total variance (less than 10\% each) and have no greater implication in the posterior clustering.

As shown in Figure 3, there is a break (elbow) that starts from the fourth principal component, which implies 4 clusters for this case. This number is adjusted from Ward's hierarchical clustering by comparing other situations (from 4 to 7 clusters) and validated by maximizing the Dunn and Silhouette indexes. Finally, the 730 subbasins delimited in the Pd were grouped into five clusters. These clusters or regions characterize the particular behavior existing in the northern zone (regions 1 and 2) of the Pd [7] and present at least one streamgage in each of them.

Table 3. Weightings of the variables and summary of characteristics on the five principal components.

\begin{tabular}{cccccc}
\hline \multirow{2}{*}{ Original Variables } & \multicolumn{5}{c}{ Principal Components } \\
\cline { 2 - 6 } & PC1 & PC2 & PC3 & PC4 & PC5 \\
\hline $\mathrm{Rm}$ & -0.457 & -0.105 & 0.221 & -0.040 & 0.147 \\
$\mathrm{Em}$ & 0.163 & 0.460 & 0.025 & 0.173 & 0.038 \\
$\mathrm{Qm}$ & -0.416 & -0.011 & 0.385 & 0.022 & 0.194 \\
$\mathrm{Rc}$ & -0.399 & 0.108 & 0.395 & 0.089 & -0.032 \\
$\mathrm{Ab}$ & -0.085 & -0.148 & -0.242 & 0.639 & -0.202 \\
$\mathrm{Sb}$ & -0.152 & -0.316 & -0.481 & -0.276 & 0.191 \\
$\mathrm{Zb}$ & -0.155 & -0.514 & 0.091 & -0.024 & -0.096 \\
$\mathrm{dc}$ & 0.098 & 0.151 & 0.167 & -0.656 & -0.339 \\
$\mathrm{fc}$ & -0.348 & 0.031 & -0.452 & -0.215 & 0.222 \\
$\mathrm{lat}$ & -0.321 & 0.407 & -0.188 & 0.011 & 0.006 \\
long & 0.253 & -0.433 & 0.250 & -0.005 & 0.016 \\
\hline Eigenvalues & 3.816 & 3.036 & 1.571 & 1.155 & 0.815 \\
Variance (\%) & 31.8 & 25.3 & 13.1 & 9.6 & 6.8 \\
Cumulative variance (\%) & 31.8 & 57.1 & 70.2 & 79.8 & 86.6 \\
\hline
\end{tabular}

\subsection{Regional Runoff Model Performance}

Five parameters of SWAT model were calibrated for 14 basins with daily flow data using the procedure described in Section 3.4. The optimal parameters for each model were obtained by evaluating the model performance in a calibration period (see Table 1) and validated in two period (as indicated in Section 3.4). Among them, the SURLAG parameter allowed to control the correct quantification of high flows as much as possible, while the parameters of GWQMN and RCHRG_DP were the most important to quantify correctly the flows from aquifers and to improve the simulated flows in dry periods. The SOL_AWC and SOL_BD parameters were important to control the flow contribution from the subsoil. 


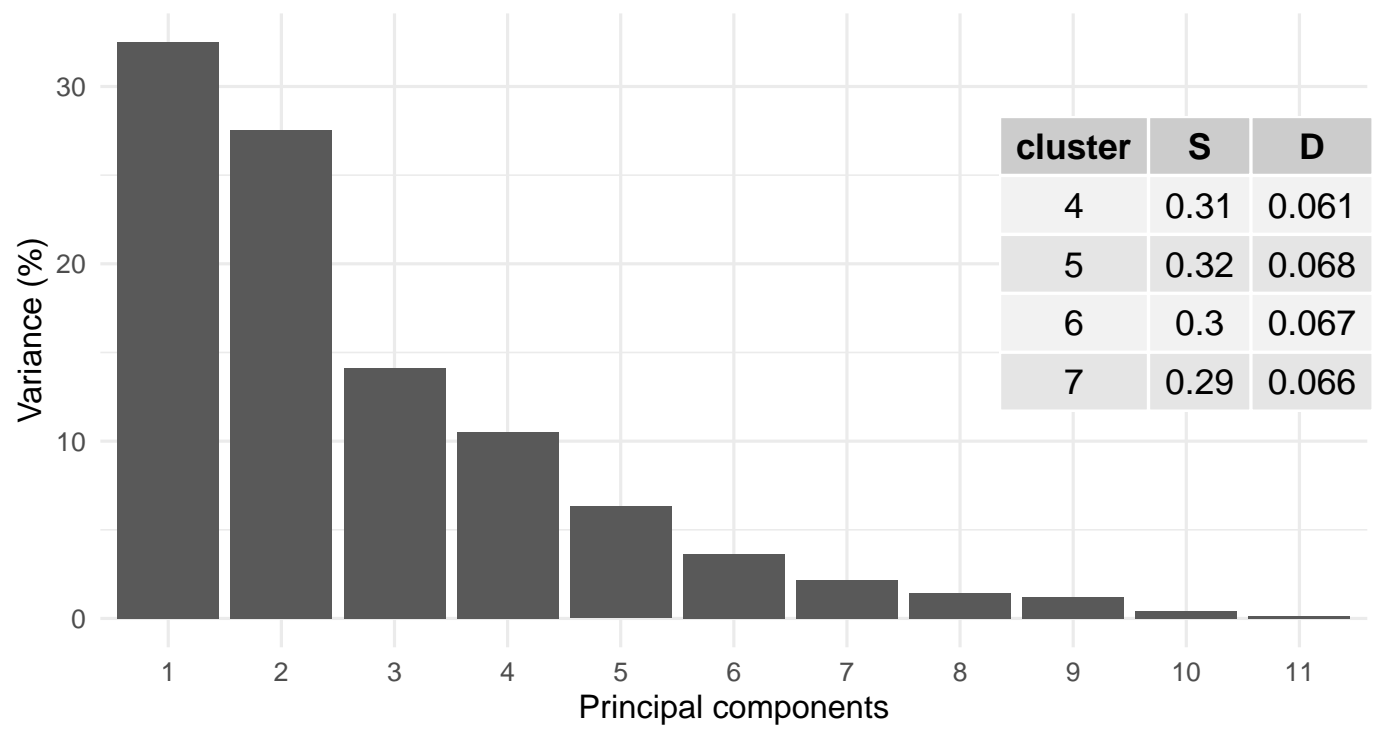

Figure 3. Percentage of variance explained as a function of the number of principal components. Dunn (D) and Silhouette (S) index are showed from 4 to 7 clusters (maximum values obtained for 5 clusters).

First, we evaluate the performance from the calibrated parameters. As can be seen in Table 4, the calibration and validation of the model gives good results based on KGE, however the model performance decrease based on the logNSE in some basins. For the whole period (1981-2016), the results show that the performance in terms of the KGE is very satisfactory (values between 0.57 and 0.84 ) and is best evident in the central and northern basins of the Pd. In terms of logNSE, low flows were estimated with lower performance (values between 0.1 and 0.8), especially in the Santa (0.16) and Tambo (0.1) basins. In general, the calibrated parameters allowed to correctly estimate the daily flows rates compared to the initial estimates (without calibration). These improvements became more evident in the low flows quantification than the simulated high flows (as discussed below in Section 4.4).

As described in Section 3.5.2, the calibrated parameters of each SWAT model were transferred to the entire Pd. Then, the regional parameters (see Table 5) were applied to estimate regional daily flows in the Pd. Figure 4 shows the performances comparison between the simulated flows from calibrated and regional parameters in the period 1981-2016. It is observed that the performance decreases when estimating the regional flow in terms of the KGE, but they are still in a satisfactory range. The regional logNSE maintains the same overall performance with respect to the calibrated $\operatorname{logNSE}$. In some cases, statistics tend to improve when applying the estimated regional parameters with respect to the previously calibrated parameters. This demonstrates the principle of equifinality of non-parsimonious models such as SWAT, where more than one parameters set can equally or better satisfy the objective function. Table 4 shows that the performance to estimate regional flows at daily step is good (average KGE of 0.58), with some exceptions in the Santa and Pisco basins (KGE 0.42 and 0.38 , respectively). In addition, acceptable results were obtained in the low flows simulations (average logNSE of 0.48 ) without considering poor performance in the Ocoña basin (from calibrated logNSE: 0.31 to regional $\log$ NSE: -2 ).

How it is seen in Figure 5, low flows are systematically underestimated during dry periods (as seen in the Chancay Huaral basin). Furthermore, the maximum daily flows are underestimated in most cases (as can be seen in the scatter plots), probably due to the loss of their representativeness when regionalizing the SURLAG parameter. 
Table 4. Overall model performance for the 14 studied basins. Performance indicators compare daily simulated and observed flow. Regional evaluation was performed from regional parameters set.

\begin{tabular}{|c|c|c|c|c|c|c|c|c|c|c|c|}
\hline \multirow{2}{*}{ No. } & \multirow{2}{*}{ River Basin } & \multicolumn{2}{|c|}{ Initial $^{\mathbf{a}}$} & \multicolumn{2}{|c|}{ Calibration $^{a}$} & \multicolumn{2}{|c|}{ Validation $^{b}$} & \multicolumn{2}{|c|}{$\begin{array}{c}\text { Whole Period } \\
\text { (1981-2016) }\end{array}$} & \multicolumn{2}{|c|}{$\begin{array}{c}\text { Regional } \\
\text { (1981-2016) }\end{array}$} \\
\hline & & KGE & $\log N S E$ & KGE & $\log N S E$ & KGE & $\log N S E$ & KGE & $\log N S E$ & KGE & $\log N S E$ \\
\hline 1 & Tumbes & 0.33 & -3.41 & 0.63 & 0.44 & 0.58 & 0.66 & 0.64 & 0.44 & 0.5 & 0.19 \\
\hline 2 & Chira & 0.37 & -3.85 & 0.72 & 0.62 & 0.7 & 0.64 & 0.75 & 0.61 & 0.69 & 0.59 \\
\hline 3 & Piura & 0.53 & 0.87 & 0.78 & 0.83 & 0.53 & 0.74 & 0.73 & 0.79 & 0.62 & 0.61 \\
\hline 4 & Chancay Lambayeque & 0.33 & -3.19 & 0.81 & 0.76 & 0.85 & 0.79 & 0.84 & 0.77 & 0.64 & 0.55 \\
\hline 5 & Chicama & 0.18 & 0.26 & 0.63 & 0.81 & 0.4 & 0.77 & 0.66 & 0.8 & 0.52 & 0.75 \\
\hline 6 & Santa & 0.14 & -7.92 & 0.57 & 0.24 & 0.59 & 0.13 & 0.57 & 0.16 & 0.42 & 0.15 \\
\hline 7 & Fortaleza & -0.18 & -0.03 & 0.8 & 0.33 & 0.59 & 0.49 & 0.74 & 0.4 & 0.7 & 0.49 \\
\hline 8 & Chancay Huaral & 0.06 & -3.51 & 0.72 & 0.54 & 0.74 & 0 & 0.73 & 0.38 & 0.59 & 0.41 \\
\hline 9 & Chillón & 0.53 & -4.06 & 0.62 & 0.48 & 0.72 & 0.63 & 0.69 & 0.54 & 0.61 & 0.54 \\
\hline 10 & Cañete & 0.15 & -1.8 & 0.6 & 0.72 & 0.71 & 0.41 & 0.69 & 0.63 & 0.5 & 0.66 \\
\hline 11 & Pisco & 0.14 & 0.52 & 0.53 & 0.72 & 0.67 & 0.35 & 0.58 & 0.62 & 0.38 & 0.6 \\
\hline 12 & Ocoña & 0.63 & -8.01 & 0.77 & 0.3 & 0.72 & 0.3 & 0.79 & 0.31 & 0.58 & -2 \\
\hline 13 & Camaná & 0.71 & -5.27 & 0.82 & 0.55 & 0.76 & 0.4 & 0.79 & 0.48 & 0.68 & 0.58 \\
\hline 14 & Tambo & 0.65 & -0.68 & 0.71 & 0.25 & 0.1 & -0.2 & 0.59 & 0.1 & 0.69 & 0.14 \\
\hline
\end{tabular}

${ }^{a}$ Tested in the calibration period indicated in Table $1 .{ }^{b}$ Tested in the subsequent period to the calibration period until December 2016.

Table 5. Regional parameters for each cluster or region.

\begin{tabular}{|c|c|c|c|c|c|c|}
\hline \multirow{2}{*}{ Parameter Name } & \multirow{2}{*}{ Parameter Description [54] } & \multicolumn{5}{|c|}{ Regional Parameters } \\
\hline & & Region 1 & Region 2 & Region 3 & Region 4 & Region 5 \\
\hline GWQMN & $\begin{array}{l}\text { Threshold depth of water in the } \\
\text { shallow aquifer required for return } \\
\text { flow to occur }\end{array}$ & 542.70 & 773.14 & 469.32 & 524.16 & 503.31 \\
\hline RCHRG_DP & Deep aquifer percolation fraction & 0.82 & 0.05 & 0.85 & 0.45 & 0.87 \\
\hline SOL_AWC ${ }^{\mathrm{r}}$ & $\begin{array}{l}\text { Available water capacity of } \\
\text { the soil layer }\end{array}$ & -86.47 & -41.00 & -83.34 & -85.37 & -12.50 \\
\hline SOL_BD ${ }^{r}$ & Soil bulk density & 22.59 & 0 & 51.67 & 19.91 & 0 \\
\hline SURLAG & Surface runoff lag coefficient & 0.40 & 1.75 & 2 & 2 & 1.06 \\
\hline
\end{tabular}

${ }^{\mathrm{r}}$ relative change of the parameter by percentage (\%) applied to default value.
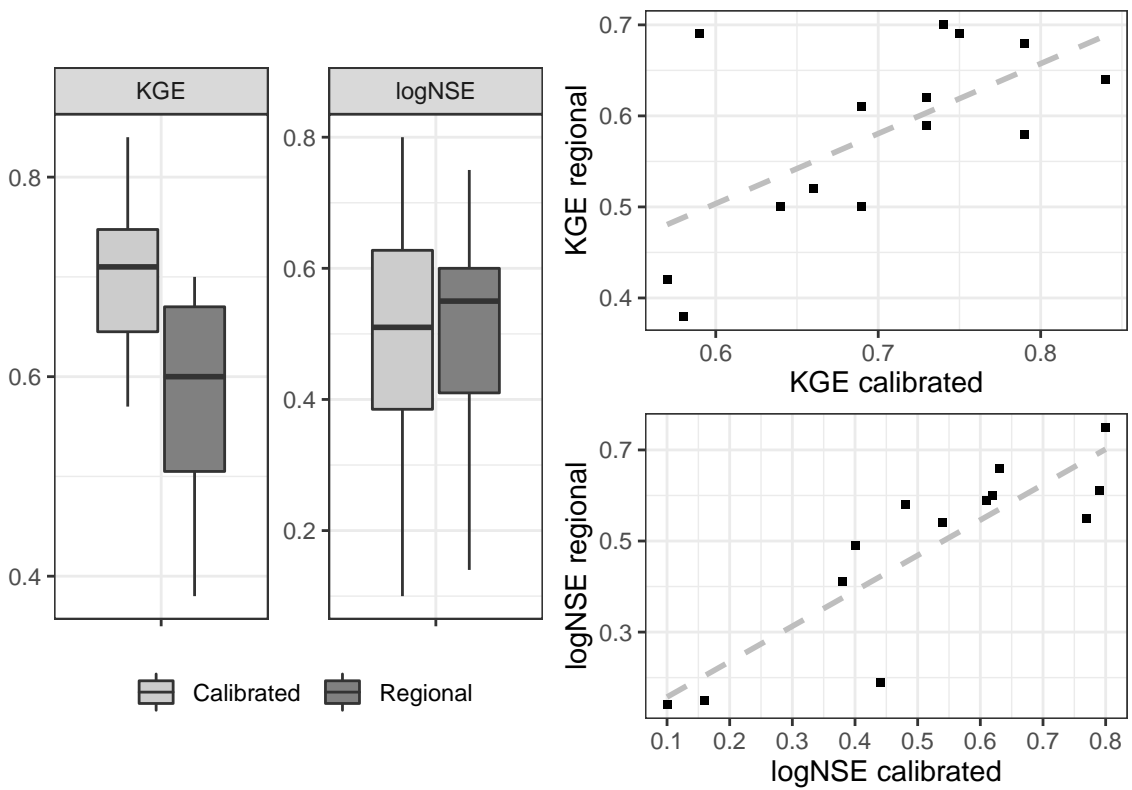

Figure 4. Comparison of the Kling-Gupta efficiency criterion (KGE) and logarithmic Nash index (logNSE) performance metrics tested from calibrated and regional parameters in the period 1981-2016 ( $\log$ NSE from Ocoña catchment was excluded in the figure). 


\subsection{Quantification of Water Resources and Water Balance}

The results presented in Figure 6 are based on the simulated time series obtained in the 730 delimited subbasins. In the Figure $6 \mathrm{a}$ it can seen the 5 regions identified by cluster analysis. Then, if a basin water balance is considered as follows: the flow contribution (Q) added to the real evapotranspiration rate (ET) is equal to the amount of precipitated rainfall (PP); Figure $6 \mathrm{~b}$ shows that subbasins belonging to lower latitudes (northern zone of the $\mathrm{Pd}$ ) have a higher water production rate compared to subbasins belonging to higher latitudes (southern zone of the $\mathrm{Pd}$ ). In addition, it is observed that losses produced by ET have an inverse pattern. The five estimated regions capture the particular characteristics of the Pd hydrological regime. Figure 6c shows that there is a marked seasonality of the Pd hydrological components for each region. It is observed that in region 1 , the contribution of $\mathrm{PP}$ is greater and consequently has greater water production. For the other regions, the PP contribution is similar in quantity. Some characteristics of the study area are observed in all regions, in which ET rates are estimated at equal or greater magnitudes than $Q$ rates. This particularity, added to the fact that the potential evapotranspiration (ETP) is much higher than the PP, is an indicator that Pd is an area predominantly arid (PP/ETP $<1$; [48]).

Figure 7 shows the results of regional flows expressed in terms of average annual specific runoff and annual runoff time series over 52 basins under natural conditions for the period 1981-2016. These results are a new contribution that complements and updates what was presented by [8]. The water availability of the Pd is quantified at the exit points near the Pacific Ocean and indicates the runoff values expressed as water yields. The maximum value of $17 \mathrm{l} / \mathrm{s} / \mathrm{km}^{2}$ corresponds to the Tumbes basin (basin furthest north in Figure 7a), while very low values (basins in red) are observed in the southern region (e.g., Caplina basin: $0.015 \mathrm{l} / \mathrm{s} / \mathrm{km}^{2}$ ). Figure $7 \mathrm{~b}$ groups the northern basins (Region 1-2), which represent the largest water contribution. Figure 7c,d (Regions 3 and 4, respectively) group the central basins, which are characterized by pluvio-nival and pluvio-glacial regimes (e.g., Santa basin). This characteristic regime of the Pd central basins is moderately reduced until reaching Figure $7 \mathrm{e}$ (Region 5), which groups basins that present the most arid conditions. The average annual runoff (black dotted line) in each region also follows a regional hydroclimatic pattern with extraordinary events during the ENSO years. This is observed for extreme El Niño events in the years 1982/1983 and $1997 / 1998$ in the northern basins. In contrast, low values are present in the southern basins during the same events.

Considering the average annual flows of the 52 basins shown in Figure 7, the total flow that drains to the Pacific Ocean in the period 1981-2016 is $990 \mathrm{~m}^{3} / \mathrm{s}$ and $872 \mathrm{~m}^{3} / \mathrm{s}$ without considering the ENSO extreme events of 1982/1983 and 1997/1998 (Figure 7f). These results are consistent with those presented by [8], in which total flow is estimated at $709 \mathrm{~m}^{3} / \mathrm{s}$ from the contribution of 49 basins, and with past studies in which only the observed flow data were considered (as listed in [3]): ELECTRO PERU in $1975\left(1025 \mathrm{~m}^{3} / \mathrm{s}\right)$, ONERN in $1980\left(855 \mathrm{~m}^{3} / \mathrm{s}\right)$, CEDEX in $1992\left(924 \mathrm{~m}^{3} / \mathrm{s}\right)$ and ANA in 2012 $\left(802 \mathrm{~m}^{3} / \mathrm{s}\right)$. From a continental hydrological perspective, considering a total flow contribution of approximately $26,540 \mathrm{~m}^{3} / \mathrm{s}$ on the western coast of South America [91], our results corroborate that the rivers along the arid Peruvian coast contribute very little flow to the ocean.

Water resources are often quantified in terms of blue water flow, which is the water yield plus the deep recharge of the aquifer. Based on [92], the storage of green water (soil moisture) has been widely recognized as a crucial component of water resources. Using the calibrated SWAT model from the regional parameters, the long-term average blue water resources (1981-2016), green water storage and green water flow (real evapotranspiration) are shown for the 730 subbasins delimited in the $\mathrm{Pd}$ (Figure 8). The results show a well-defined spatial variation that is mainly a function of altitude and related to rainfall patterns. Blue water resources, green water storage and green water flow are greater in the middle and upper parts of the basins. The blue water flow (green water storage) has a greater presence in the north (south) zone, while the green water flow has a uniform distribution throughout the Pd. One way to take advantage of this information is by identifying areas with lower blue water resources and higher soil moisture because they are areas that have greater potential for the rainfed 
agriculture development, an important production activity in Peru. The runoff-rainfall ratio map (a derivative blue water map) serves as an indicator of erosion potential, which is predominantly higher in the northern zone, usually due to the high rainfall rates. It should be noted that the estimated storage and green water flow were not directly calibrated since there were no direct observations; however, they are presented here as a first quantification of these resources for the $\mathrm{Pd}$.
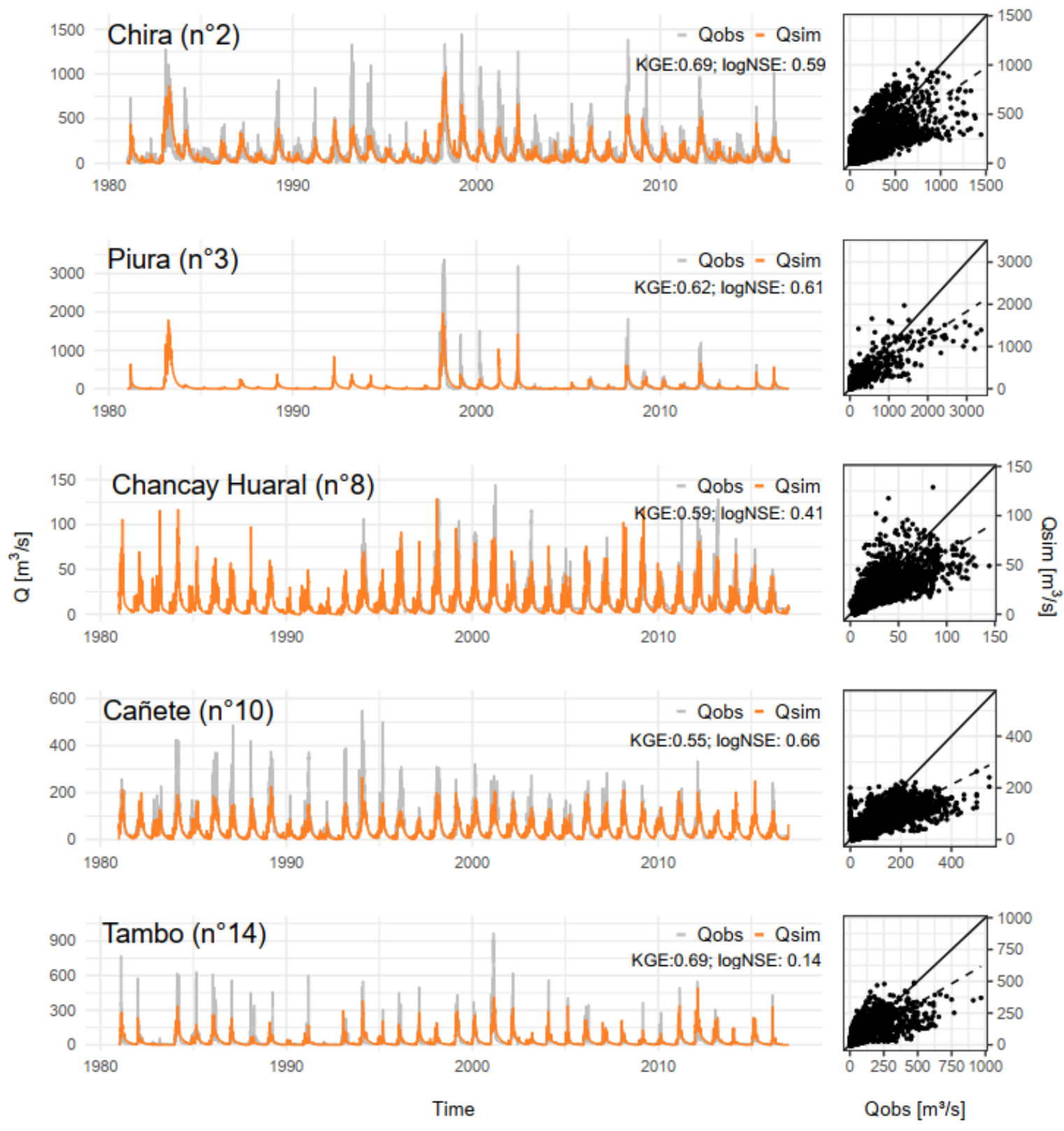

Figure 5. Daily hydrographs of the observed and simulated (regional) flows for one basin by region in the period 1981-2016.

\subsection{Performance of the Uncertainty Bands at Streamgages}

As explained in Section 3.6, the uncertainty bands (UB) evaluation was carried out based on the coverage ratio $(C R)$ and the Average width index $(A W I)$. The $C R$ ranges from approximately 0.19 to 0.81 , with mean and median values of 0.57 and 0.63 respectively. This $C R$ is lower than those obtained in previous studies [88-90], which is explained given the different methodologies applied when estimating UB. The AWI analysis indicates that the UB are in a scenario in which they reduce the uncertainty of the simulated flows in comparison with the climatology natural variability (average of 
AWI 0.82 in a range of 0.72 and 0.90 ). The satisfactory values of $A W I$ is the result of all criterions taken in the parameters sensitivity analysis when calibrating the SWAT model (explained in Section 3.4); in this way, the values obtained do not differ much from each other, producing that simulated flow time series variability in the bootstrapping are not extremely wide in all streamgages analyzed.
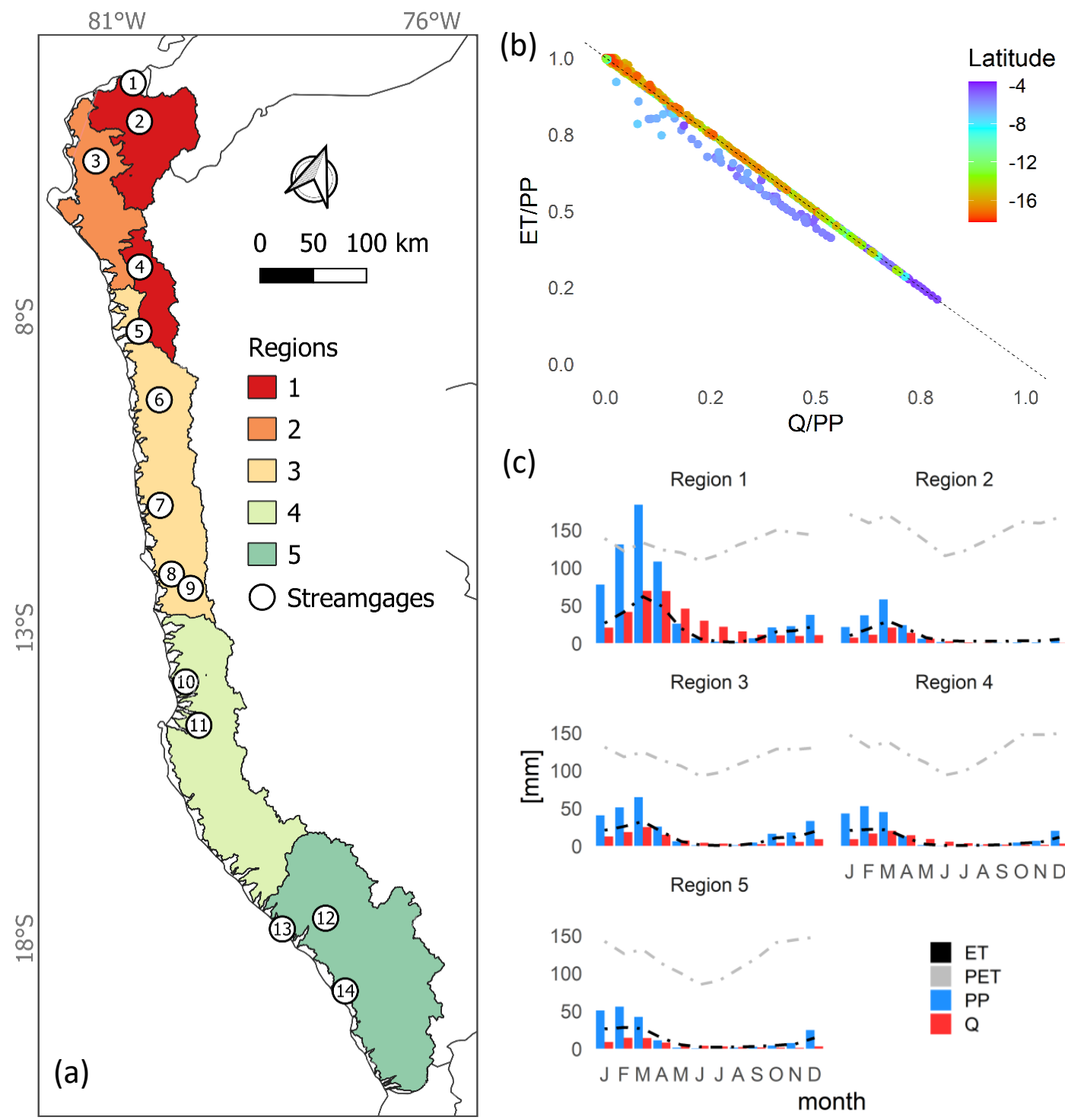

(c)

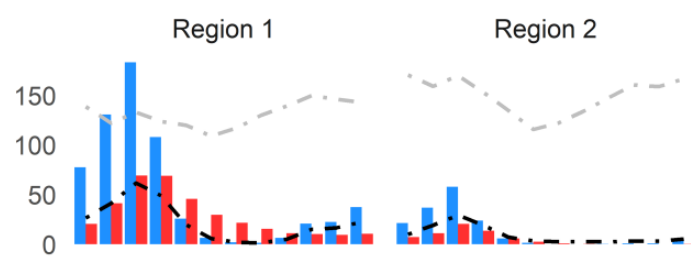

Region 3

Region 4
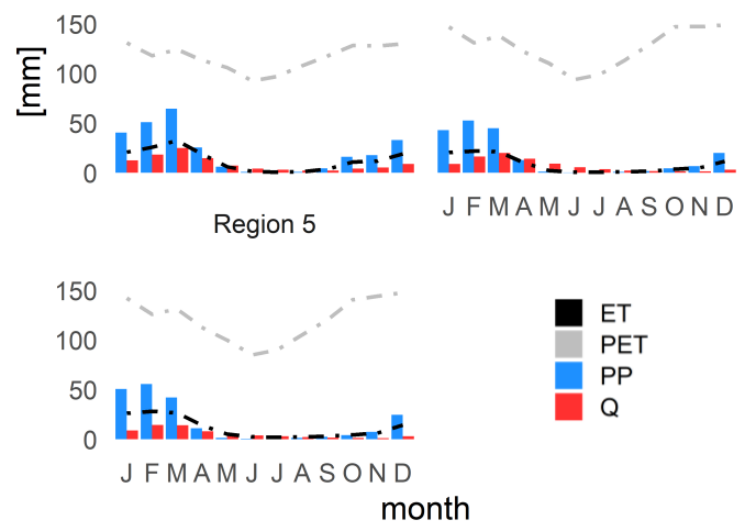

Figure 6. Water balance of Pacific subbasins. (a) Regions estimated by clustering, (b) Real evapotranspiration ratio (ET/PP) and flow ratio (Q/PP) calculated for each subbasin, (c) Hydrological components seasonality estimated in each region. Enumerated streamgages listed in Table 1.

Figure 9 shows that the KGE and $C R$ values show a similar variability pattern (medians of 0.60 and 0.63 respectively). In addition, the $C R$ values tend to show a positive correlation with the hydrological modeling performance (KGE). In some cases, a good KGE performance can be related to different $C R$ values and viceversa. In the case of $A W I$, independent of the KGE values, is showed values between 0.7 and 0.9 . There is not much variability in this index, so it is inferred that the $A W I$ would always remain in that range if more streamgages were included in the analysis. 
(b)

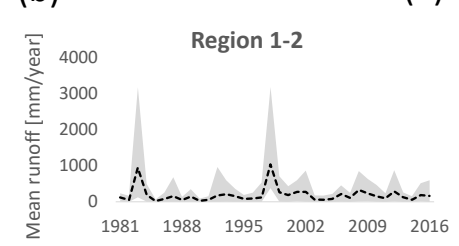

(c)

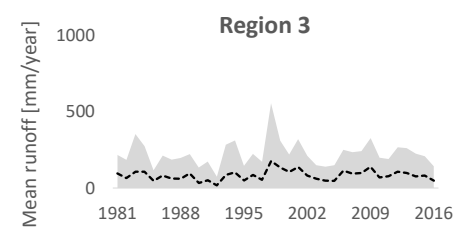

(d)

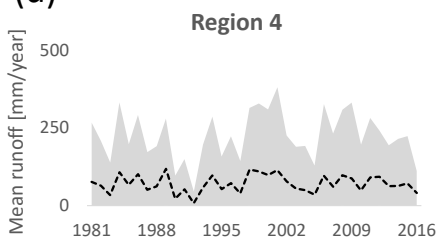

(f)

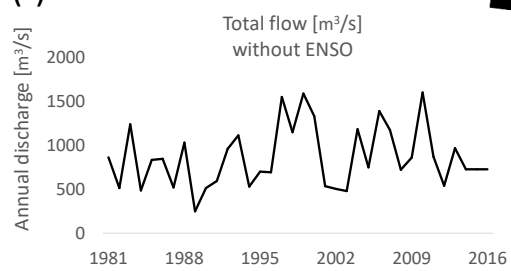

(a)

(3)

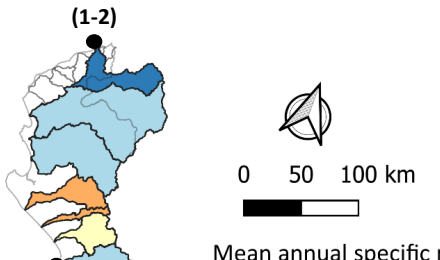

Mean annual specific runoff $\mathrm{l} / \mathrm{s} / \mathrm{Km}^{2}$

0 - 1

$\square$ - 3

3-6

$6-11$

$11-20$

Peruvian Pacific drainage

Simulated time series

----Average

(e)

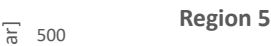

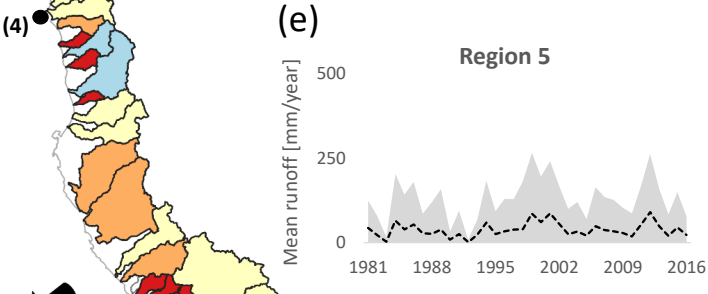

(5)

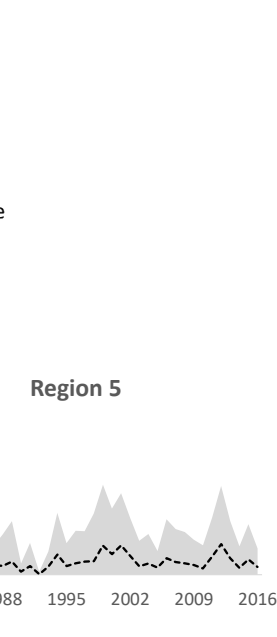

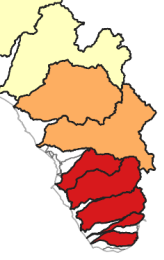

Figure 7. Spatial distribution of natural runoff (1981-2016) estimated by over 52 Pacific drainage basins. (a) Mean annual specific runoff by basin. (b-e) Annual time series and runoff variability grouped by region. (f) Total annual flow reaching $872 \mathrm{~m}^{3} / \mathrm{s}$. Region (1-2), (3), (4) and (5) starts at Tumbes, Chancay Lambayeque, Rimac and Ocoña basin respectively.

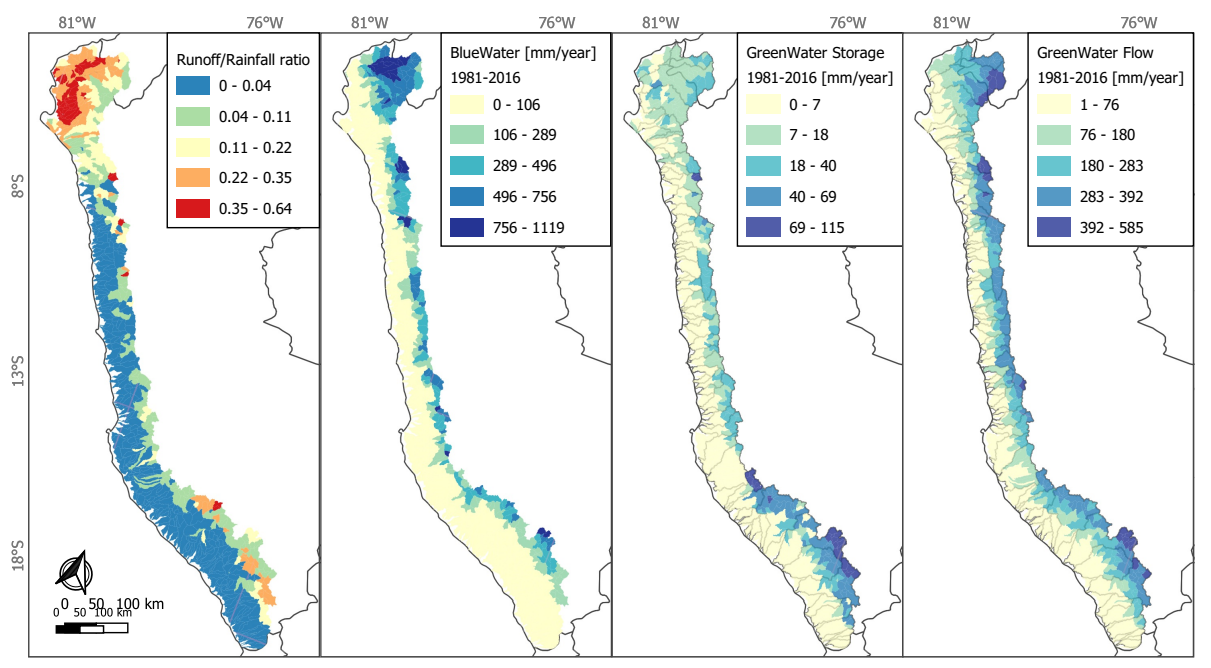

Figure 8. Spatial distribution of hydrological components showed as: Runoff/Rainfall ratio, Blue Water, Green Water (Storage) and Green Water (Flow) for the Pacific drainage subbasins. 
Considering all the UB and observed daily flow of the 14 streamgages, Figure 10 shows that the $C R$ values vary from month to month. The UB contains a higher (lower) proportion of the observed flow in dry (wet) periods during May-November (December-April). It is not the objective of the present study, but this analysis establishes that the estimated regional parameters for SWAT model do not allow to quantify correctly the maximum flows in the considered streamgages along the Pd. The UB for December-April contain, on average, $50 \%$ of the observed flows.
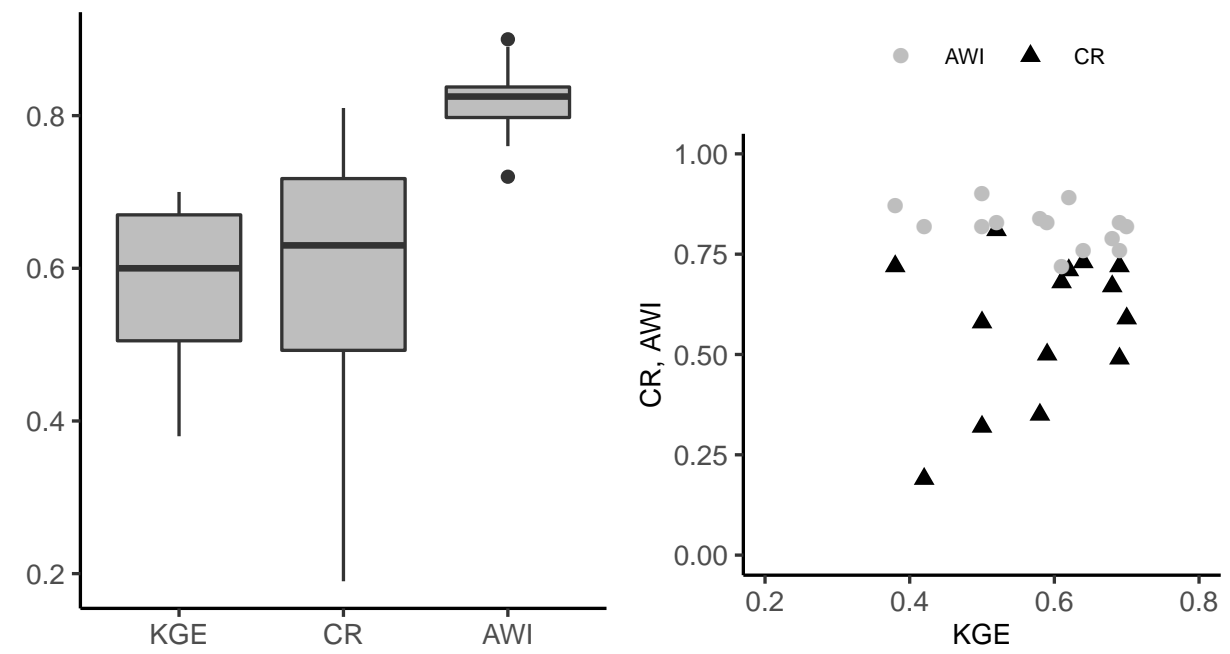

Figure 9. (Left): Distribution of simulated flow performance (KGE) and uncertainty intervals performance (CR, AWI). (Right): Relationship between KGE and its respectives CR and AWI values on 14 streamgages of Pacific drainage.

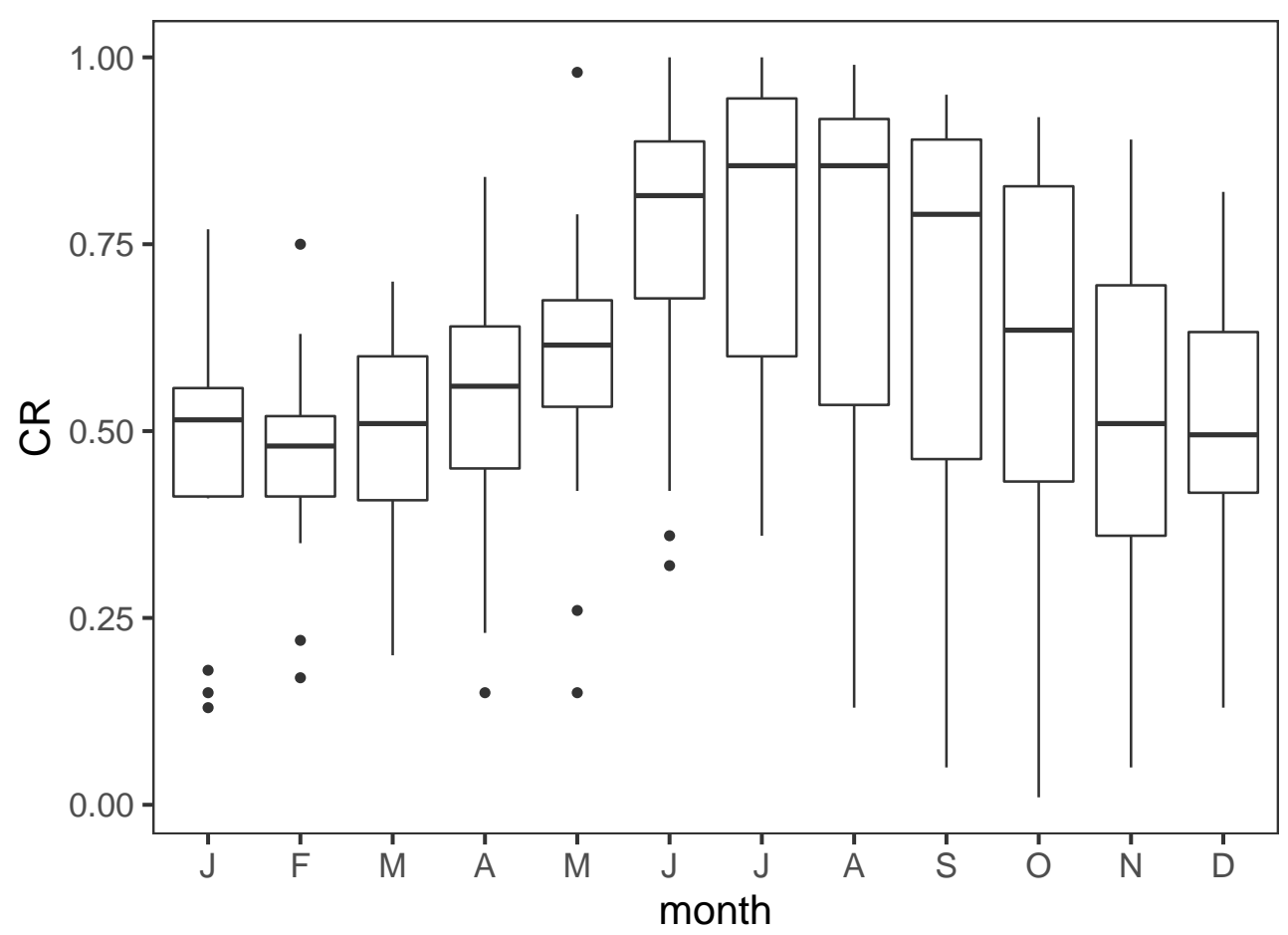

Figure 10. Coverage ratio per month based on the uncertainty intervals from 14 streamgages along Pacific drainage. 


\section{Discussion}

\subsection{Subjectivity in the Physical Similarity Approach by Clustering}

This article presents a methodology for flow rates estimation through hydrological modeling following a parameter regionalization approach. Although the SWAT model was used, the selected regionalization method is independent of the chosen hydrological model. The regionalization technique is based on the similarity approach, a method that transfers the optimal parameters set from calibrated hydrographic basins to similar hydrographic basins. In addition, this method is recommended over regression and spatial proximity methods $[12,16,18,23]$ and has shown good performance in hydrological modeling in arid zones [18,93]. In our work, similarity is defined by subbasins grouping with physical and hydroclimatic characteristics that try to explain the hydrological behavior. Although the PCA prior to the definition of clusters or regions eliminates much of subjectivity when selecting the most influential similarity variables, it should be mentioned that the basin characteristics most commonly available (topography, land use, soil and climate) are not sufficient to fully explain the hydrological response $[17,94,95]$, and it is suggested to incorporate additional basin characteristics [11]. It is likely that this includes hydrogeological characteristics and/or basin flow regulation characteristics [30], data of difficult availability in the Pd.

\subsection{Physical Implications of the Regional Parameter Set}

The results of this study indicate that the five regionalized parameters can be used to produce satisfactory simulations from SWAT model in the Pd. The values shown in Table 5 are mainly related to the climatic conditions of the study area. In the case of the RCHRG_DP parameter, the high values obtained (close to 0.9 ) indicate that the $\mathrm{Pd}$ is an area where rivers are predominantly recharged by aquifers and have high potential for water harvesting [96]. Previous studies have observed that the SWAT model underestimates low flow rates in dry and wet periods $[97,98]$, and consequently, the model has been modified and even coupled to other models (e.g., MODFLOW). to improve the flow contributions from aquifers [99-102]. It is not the objective of the present study to modify the SWAT source code, but we emphasize the importance of calibrating the RCHRG_DP parameter to improve the low flows representativeness, especially in Pd basins. In addition, this parameter sensitivity is evident when it is regionalized; for example, in the Ocoña river basin, the performance of the logNSE decreases considerably (see Table 4) because the value of RCHRG_DP is reduced, which causes the model to underestimate dry periods flow. Set a suitable threshold (GWQMN) for there to be a contribution from the aquifer is also very important. For the Pd, these values are between 500 and $800 \mathrm{~mm}$ and allowed to correct the initial low flows underestimations. Although in SWAT the groundwater routine is very simplistic, these first results suggest the need for detailed groundwater studies in the Pd and to have a better physical interpretability of these parameters.

The parameter values of SOL_AWC and SOL_BD indicate that the Pd is characterized by an arid climate and a predominantly sandy soil (Table 1). The percentage increase of SOL_BD is related to lighter soils that have a lower water holding capacity than heavier or clayey soils. On the other hand, the high rates of potential evapotranspiration (Figure 6) in arid climates generate high water losses to the atmosphere. The parameter SOL_AWC allows to regulate the amount of available water in the soil for the evapotranspiration process, and a decrease in its value corrects the initial underestimations of SWAT model and thus improves the initial performance of the KGE (Table 4). Finally, the SURLAG parameter is important to correctly simulate the high flows according to its physical definition (see Table 5). From the initial SURLAG calibrated parameters, the simulated high flows generally underestimated the observed ones in most of the studied basins; however, this was a fairly acceptable underestimation. Although the PISCO rainfall product does not correctly capture the intensity of the rainfall [57], one of the main factors of the low representativeness of high flows could be attributed when the flow is obtained from the regional SURLAG parameters (as shown in Figure 5). In the present work, greater importance was given to the water balance representation, and we indicate 
that for a better high flow estimation, it is recommended to condition the SWAT calibration based on indices that evaluate only the extreme flows behavior.

\subsection{Conditionality of the SWAT Calibrated Model and Its Applicability}

It should be noted from the beginning that hydrological models calibration is subjective and that no automatic calibration algorithm can replace the analyst knowledge in relation to the basin hydrology and calibration problems. Therefore, the calibration and uncertainty analysis are closely linked, and calibration results should not be presented without an uncertainty degree quantification in the model predictions [24]. In this context, the uncertainty analyzed in this study serves as a first approximation to evaluate the calibrated parameters set performance obtained by each region. While we use bootstrapping to increase the number of available parameters per region and to present a more consistent analysis of the UB, we can say that the uncertainty associated with regionalization process has yielded good results mainly due to the criterions used in the calibration process to reduce the equifinality of SWAT model. It is understood that more streamgages should be taken into account for a better analysis; however, indicating the processes that the model is not adequately representing is a "high value information" for decision makers. Based on the above, the water resources quantification in the Pd presented here should be taken into account according to the objectives for which the SWAT model was built. Having a regional model that estimates natural flow series and correctly represents the Pd basins water balance is useful for identifying long-term relationships with climate variability and climate change impacts, and to be applied for water resource management purposes.

\section{Summary and Conclusions}

This study proposes a methodology for daily flows estimation in the Pacific drainage of Peru from a physically based model (SWAT). In most large-scale hydrological models, the calibration process of model parameters is critical and even more so for areas with limited availability of hydrological data. A parameter transfer method was proposed based on an approach of physical similarity and clustering that divided the Pacific drainage (divided in 730 subbasins) into five regions assumed to be hydrologically homogeneous. Fourteen basins were calibrated to subsequently estimate the regional parameters based on the median of the calibrated parameters set available in each region. As a first approximation to evaluate the methodology robustness in the parameter regionalization process, by means of statistical techniques such as bootstrapping, the uncertainty bands were derived in each evaluated basin. The results show that the SWAT model with regional parameters can simulate the observed flows well and correctly represent the seasonality of the hydrological cycle main components. The high rates of potential evapotranspiration on precipitation and the particular flow behavior in the northern zone of the Pacific drainage are equally well represented.

At the annual level, flow series pattern variability along the drainage and the total flow contribution to the Pacific Ocean show similarity with previous studies. Certain relationships were found between values of the calibrated parameters and physical-climatic characteristics of the basins studied; however, a greater analysis was not possible due to the absence of observed data to support our assumptions. Similarly, the water resources quantification based on components of blue water, green water storage (soil moisture) and green water flow (real evapotranspiration) allowed us to obtain a better understanding of water availability and variability in the Pacific basins, which should serve as a tool for better use and management of its water resources. The evaluation of derived uncertainty bands indicated that the high flows are not correctly quantified; however, the natural variability of observed flow climatology is well represented. These results support the idea that flows are better simulated from a calibrated model than from a regionalized model. In addition, the idea is supported that the best way to handle the problem of rainfall-runoff modeling in uncalibrated basins would be to install a streamgage. 
The present study adds to the research efforts in the hydrological modeling field at the regional scale that have been carried out in recent years on the Peruvian Pacific drainage. A first step is presented to expand the use and development of physical bases hydrological models for their application at a regional scale, and the presented parameters transfer approach is promising to estimate SWAT parameters in areas with scarce hydrological data in Peru. Future studies will be dedicated to investigating the flow rates sensitivity in a context of climate change and exploring calibration techniques in hydrological modeling to correctly estimate annual maximum daily flows.

Supplementary Materials: The metadata is available online at: https://figshare.com/articles/dataset/SWAT_ Pacifico_main_outputs/13236941.

Author Contributions: Conceptualization, F.A.A.-V., W.S.L.-C.; Formal analysis, F.A.A.-V., W.S.L.-C.; Investigation, F.A.A.-V., W.S.L.-C.; Methodology, F.A.A.-V., W.S.L.-C.; Software, F.A.A.-V., Writing-review \& editing, F.A.A.-V., W.S.L.-C., Supervision, F.A.A.-V., W.S.L.-C. All authors have read and agreed to the published version of the manuscript.

Funding: This research was funded by the Swiss Agency for Development and Cooperation (SDC) and implemented by South South North (SSN) and Libélula Institute of Global Change under the direction of the Environment Ministry of Peru (Ministerio del Ambiente-MINAM).

Acknowledgments: We thank all the support offered in the framework of the project "Apoyo a la Gestión del Cambio Climático Segunda Fase (período 2019-2021)". Likewise, we thank the technical-scientific support provided and the hydrological data shared by the Hydrology Department of the National Service of Meteorology and Hydrology of Peru (SENAMHI).

Conflicts of Interest: The authors declare no conflict of interest.

\section{References}

1. Garreaud, R.; Vuille, M.; Compagnucci, R.; Marengo, J. Present-day South American climate. Paleogeogr. Palaeoclimatol. Paleoecol. 2009, 281, 180-195. [CrossRef]

2. Ruiz, R.; Torres, H.; Aguirre, M. Delimitación y Codificación de Unidades Hidrográficas del Perú; Autoridad Nacional del Agua-Ministerio de Agricultura: Lima, Perú, 2008.

3. ANA. Recursos Hídricos en el Perú; Technical Report; Ministerio de Agricultura: Lima, Perú, 2012.

4. PRB. World Population Data Sheet (Population Reference Bureau); PRB: Washington, DC, USA, 2020.

5. FAO. FAO Statistical Yearbook 2013: World Food and Agriculture; FAO: Rome, Italy, 2013.

6. Lavado, W.S.; Ronchail, J.; Labat, D.; Espinoza, J.C.; Guyot, J.L. Basin-scale analysis of rainfall and runoff in Peru (1969-2004): Pacific, Titicaca and Amazonas drainages. Hydrol. Sci. J. 2012, 57, 625-642, [CrossRef]

7. Rau, P.; Bourrel, L.; Labat, D.; Melo, P.; Dewitte, B.; Frappart, F.; Lavado, W.; Felipe, O. Regionalization of rainfall over the Peruvian Pacific slope and coast. Int. J. Climatol. 2017, 37, 143-158. [CrossRef]

8. Rau, P.; Bourrel, L.; Labat, D.; Ruelland, D.; Frappart, F.; Lavado, W.; Dewitte, B.; Felipe, O. Assessing multidecadal runoff (1970-2010) using regional hydrological modelling under data and water scarcity conditions in Peruvian Pacific catchments. Hydrol. Process. 2019, 33, 20-35, [CrossRef]

9. Seiller, G.; Anctil, F.; Perrin, C. Multimodel evaluation of twenty lumped hydrological models under contrasted climate conditions. Hydrol. Earth Syst. Sci. 2012, 16,1171-1189. [CrossRef]

10. Beck, H.E.; van Dijk, A.I.; De Roo, A.; Miralles, D.G.; McVicar, T.R.; Schellekens, J.; Bruijnzeel, L.A. Global-scale regionalization of hydrologic model parameters. Water Resour. Res. 2016, 52, 3599-3622. [CrossRef]

11. Oudin, L.; Kay, A.; Andréassian, V.; Perrin, C. Are seemingly physically similar catchments truly hydrologically similar? Water Resour. Res. 2010, 46, [CrossRef]

12. Oudin, L.; Andréassian, V.; Perrin, C.; Michel, C.; Le Moine, N. Spatial proximity, physical similarity, regression and ungaged catchments: A comparison of regionalization approaches based on 913 French catchments. Water Resour. Res. 2008, 44, 1-15, [CrossRef]

13. Stoll, S.; Weiler, M. Explicit simulations of stream networks to guide hydrological modelling in ungauged basins. Hydrol. Earth Syst. Sci. 2010, 14, 1435-1448, [CrossRef] 
14. Samuel, J.; Coulibaly, P.; Metcalfe, R.A. Estimation of continuous streamflow in Ontario ungauged basins: comparison of regionalization methods. J. Hydrol. Eng. 2011, 16, 447-459, [CrossRef]

15. Parajka, J.; Viglione, A.; Rogger, M.; Salinas, J.; Sivapalan, M.; Blöschl, G. Comparative assessment of predictions in ungauged basins-Part 1: Runoff hydrograph studies. Hydrol. Earth Syst. Sci. Discuss. 2013, 10, [CrossRef]

16. Razavi, T.; Coulibaly, P. Streamflow Prediction in Ungauged Basins: Review of Regionalization Methods. J. Hydrol. Eng. 2013, 18, 958-975, [CrossRef]

17. Merz, R.; Blöschl, G. Regionalisation of catchment model parameters. J. Hydrol. 2004, 287, 95-123. [CrossRef]

18. Parajka, J.; Merz, R.; Blöschl, G. A comparison of regionalisation methods for catchment model parameters. Hydrol. Earth Syst. Sci. 2005, 9, 157-171. [CrossRef]

19. McIntyre, N.; Lee, H.; Wheater, H.; Young, A.; Wagener, T. Ensemble predictions of runoff in ungauged catchments. Water Resour. Res. 2005, 41. [CrossRef]

20. Bárdossy, A. Calibration of hydrological model parameters for ungauged catchments. Eur. Geosci. Union 2007, 11, 703-710, [CrossRef]

21. Zhang, Y.; Chiew, F.H. Relative merits of different methods for runoff predictions in ungauged catchments. Water Resour. Res. 2009, 45. [CrossRef]

22. Merz, R.; Blöschl, G.; Parajka, J.D. Regionalization methods in rainfall-runoff modelling using large catchment samples. IAHS Publ. 2006, 307, 117.

23. Arsenault, R.; Brissette, F.P. Continuous streamflow prediction in ungauged basins: The effects of equifinality and parameter set selection on uncertainty in regionalization approaches. J. Am. Water Resour. Assoc. 2014, 50, 6135-6153, [CrossRef]

24. Abbaspour, K.C.; Rouholahnejad, E.; Vaghefi, S.; Srinivasan, R.; Yang, H.; Kløve, B. A continental-scale hydrology and water quality model for Europe: Calibration and uncertainty of a high-resolution large-scale SWAT model. J. Hydrol. 2015, 524, 733-752, [CrossRef]

25. Arnold, J.G.; Srinivasan, R.; Muttiah, R.S.; Williams, J.R. Large area hydrologic modeling and assessment part I: Model development 1. JAWRA J. Am. Water Resour. Assoc. 1998, 34, 73-89. [CrossRef]

26. Gitau, M.W.; Chaubey, I. Regionalization of SWAT model parameters for use in ungauged watersheds. Water 2010, 2, 849-871, [CrossRef]

27. Swain, J.B.; Patra, K.C. Streamflow estimation in ungauged catchments using regionalization techniques. J. Hydrol. 2017, 554, 420-433, [CrossRef]

28. Van Liew, M.W.; Mittelstet, A.R. Comparison of three regionalization techniques for predicting streamflow in ungaged watersheds in nebraska, USA using SWAT model. Int. J. Agric. Biol. Eng. 2018, 11, 110-119, [CrossRef]

29. Choubin, B.; Solaimani, K.; Rezanezhad, F.; Habibnejad Roshan, M.; Malekian, A.; Shamshirband, S. Streamflow regionalization using a similarity approach in ungauged basins: Application of the geo-environmental signatures in the Karkheh River Basin, Iran. Catena 2019, 182, 104128, doi:10.1016/j.catena.2019.104128. [CrossRef]

30. Pagliero, L.; Bouraoui, F.; Diels, J.; Willems, P.; McIntyre, N. Investigating regionalization techniques for large-scale hydrological modelling. J. Hydrol. 2019, 570, 220-235, doi:10.1016/j.jhydrol.2018.12.071. [CrossRef]

31. Molina, L.A.U. Validacion del Modelo Hidrologico SWAT, con interfaz Arcview, en la cuenca alta del rio Chama, estado Merida. Rev. For. Venez. 2005, 49, 105-106.

32. Stehr, A.; Debels, P.; Romero, F.; Alcayaga, H. Hydrological modelling with SWAT under conditions of limited data availability: Evaluation of results from a Chilean case study. Hydrol. Sci. J. 2008, 53, 588-601. [CrossRef]

33. Stehr, A.; Debels, P.; Arumi, J.L.; Romero, F.; Alcayaga, H. Combining the Soil and Water Assessment Tool (SWAT) and MODIS imagery to estimate monthly flows in a data-scarce Chilean Andean basin. Hydrol. Sci. J. 2009, 54, 1053-1067. [CrossRef]

34. Barrios, A.G.; Urribarri, L.A. Aplicación del modelo Swat en los Andes venezolanos: Cuenca alta del río Chama. Rev. Geográfica Venez. 2010, 51, 11-29.

35. Alarcon, V.J.; Alcayaga, H.; Álvarez, E. Hydrological modeling of an ungauged watershed in Southern Andes. In AIP Conference Proceedings; AIP Publishing LLC: Melville, NY, USA, 2015; Volume 1702, p. 190003. 
36. Yacoub, C.; Pérez-Foguet, A. Assessment of terrain slope influence in SWAT modeling of Andean watersheds. EGUGA 2009,11, 6381.

37. Uribe, N.; Quintero, M.; Valencia, J. Aplicación del Modelo Hidrológico SWAT (Soil and Water Assessment Tool) a la Cuenca del Río Cañete (SWAT); Technical Report; International Center for Tropical Agriculture: Cali, Colombia, 2013.

38. Lavado Casimiro, W.S.; Labat, D.; Guyot, J.L.; Ardoin-Bardin, S. Assessment of climate change impacts on the hydrology of the Peruvian Amazon-Andes basin. Hydrol. Process. 2011, 25, 3721-3734. [CrossRef]

39. Andres, N.; Vegas Galdos, F.; Lavado Casimiro, W.S.; Zappa, M. Water resources and climate change impact modelling on a daily time scale in the Peruvian Andes. Hydrol. Sci. J. 2014, 59, 2043-2059. [CrossRef]

40. Zulkafli, Z.; Buytaert, W.; Manz, B.; Rosas, C.V.; Willems, P.; Lavado-Casimiro, W.; Guyot, J.L.; Santini, W. Projected increases in the annual flood pulse of the Western Amazon. Environ. Res. Lett. 2016, 11, 014013. [CrossRef]

41. Olsson, T.; Kämäräinen, M.; Santos, D.; Seitola, T.; Tuomenvirta, H.; Haavisto, R.; Lavado-Casimiro, W. Downscaling climate projections for the Peruvian coastal Chancay-Huaral Basin to support river discharge modeling with WEAP. J. Hydrol. Reg. Stud. 2017, 13, 26-42, [CrossRef]

42. Lavado Casimiro, W.S.; Labat, D.; Guyot, J.L.; Ronchail, J.; Ordonez, J.; others. TRMM rainfall data estimation over the Peruvian Amazon-Andes basin and its assimilation into a monthly water balance model. In New Approaches to Hydrological Prediction in Datasparse Regions, Proceedings of Symposium HS; IAHS Press: Hyderabad, India, 2009; Volume 2, pp. 207-216.

43. Zulkafli, Z.; Buytaert, W.; Onof, C.; Manz, B.; Tarnavsky, E.; Lavado, W.; Guyot, J.L. A comparative performance analysis of TRMM 3B42 (TMPA) versions 6 and 7 for hydrological applications over Andean-Amazon river basins. J. Hydrometeorol. 2014, 15, 581-592. [CrossRef]

44. Zubieta, R.; Getirana, A.; Espinoza, J.C.; Lavado, W. Impacts of satellite-based precipitation datasets on rainfall-runoff modeling of the Western Amazon basin of Peru and Ecuador. J. Hydrol. 2015, 528, 599-612. [CrossRef]

45. Strauch, M.; Kumar, R.; Eisner, S.; Mulligan, M.; Reinhardt, J.; Santini, W.; Vetter, T.; Friesen, J. Adjustment of global precipitation data for enhanced hydrologic modeling of tropical Andean watersheds. Clim. Chang. 2017, 141, 547-560. [CrossRef]

46. Satgé, F.; Ruelland, D.; Bonnet, M.P.; Molina, J.; Pillco, R. Consistency of satellite precipitation estimates in space and over time compared with gauge observations and snow-hydrological modelling in the lake Titicaca region. Hydrol. Earth Syst. Sci. 2018, 1-41.

47. De Reparaz, G. Los Ríos de la Zona árida Peruana; Universidad de Piura: Piura, Perú, 2013.

48. Rau, P.; Bourrel, L.; Labat, D.; Frappart, F.; Ruelland, D.; Lavado, W.; Dewitte, B.; Felipe, O. Hydroclimatic change disparity of Peruvian Pacific drainage catchments. Theor. Appl. Climatol. 2018, 134, 139-153, [CrossRef]

49. Lavado, W.; Espinoza, J.C. Impactos de El Niño y La Niña en las lluvias del Perú (1965-2007). Rev. Bras. Meteorol. 2014, 29, 171-182. [CrossRef]

50. Bourrel, L.; Rau, P.; Dewitte, B.; Labat, D.; Lavado, W.; Coutaud, A.; Vera, A.; Alvarado, A.; Ordoñez, J. Low-frequency modulation and trend of the relationship between ENSO and precipitation along the northern to centre Peruvian Pacific coast. Hydrol. Process. 2015, 29, 1252-1266. [CrossRef]

51. Sanabria, J.; Bourrel, L.; Dewitte, B.; Frappart, F.; Rau, P.; Solis, O.; Labat, D. Rainfall along the coast of Peru during strong El Niño events. Int. J. Climatol. 2018, 38, 1737-1747. [CrossRef]

52. Vargas, P. El Cambio Climático y sus Efectos en el Perú; Banco Central de Reserva del Perú: Lima, Perú, 2009.

53. Arnold, J.; Allen, P. Estimating hydrologic budgets for three Illinois watersheds. J. Hydrol. 1996, 176, 57-77. [CrossRef]

54. Neitsch, S.; Arnold, J.; Kiniry, J.; Williams, J. Soil \& Water Assessment Tool Theoretical Documentation Version 2009; Texas Water Resour Inst.: Forney, TX, USA, 2011; pp. 1-647.

55. Chaplot, V. Impact of DEM mesh size and soil map scale on SWAT runoff, sediment, and NO3-N loads predictions. J. Hydrol. 2005, 312, 207-222. [CrossRef]

56. Bormann, H.; Breuer, L.; Gräff, T.; Huisman, J.; Croke, B. Assessing the impact of land use change on hydrology by ensemble modelling (LUCHEM) IV: Model sensitivity to data aggregation and spatial (re-) distribution. Adv. Water Resour. 2009, 32, 171-192. [CrossRef] 
57. Aybar, C.; Fernández, C.; Huerta, A.; Lavado, W.; Vega, F.; Felipe-Obando, O. Construction of a high-resolution gridded rainfall dataset for Peru from 1981 to the present day. Hydrol. Sci. J. 2019, 65, 770-785. [CrossRef]

58. Huerta, A.; Aybar, C.; Lavado, W. PISCO Tem-Perature v.1.1.; Technical Report; SENAMHI: Lima, Perú, 2018.

59. Lehner, B.; Verdin, K.; Jarvis, A. New global hydrography derived from spaceborne elevation data. Eos Trans. Am. Geophys. Union 2008, 89, 93-94. [CrossRef]

60. Bontemps, S.; Defourny, P.; Radoux, J.; Van Bogaert, E.; Lamarche, C.; Achard, F.; Mayaux, P.; Boettcher, M.; Brockmann, C.; Kirches, G.; et al. Consistent global land cover maps for climate modelling communities: Current achievements of the ESA's land cover CCI. In Proceedings of the ESA Living Planet Symposium, Edimburgh, UK, 9-13 September 2013; pp. 9-13.

61. FAO-UNESCO. Soil Map of the World; Technical Report South America; FAO-UNESCO: Rome, Italy, 1971.

62. Dile, Y.T.; Daggupati, P.; George, C.; Srinivasan, R.; Arnold, J. Introducing a new open source GIS user interface for the SWAT model. Environ. Model. Softw. 2016, 85, 129-138. [CrossRef]

63. Luo, Y.; Su, B.; Yuan, J.; Li, H.; Zhang, Q. GIS techniques for watershed delineation of SWAT model in plain polders. Procedia Environ. Sci. 2011, 10, 2050-2057. [CrossRef]

64. Hargreaves, G.H.; Samani, Z.A. Reference crop evapotranspiration from temperature. Appl. Eng. Agric. 1985, 1, 96-99. [CrossRef]

65. Priestley, C.H.B.; Taylor, R. On the assessment of surface heat flux and evaporation using large-scale parameters. Mon. Weather. Rev. 1972, 100, 81-92. [CrossRef]

66. Monteith, J. Evaporation and environment. The state and movement of water in living organisms. In Symposium of the Society of Experimental Biology; Cambridge Univ. Press: Cambridge, UK, 1965; Volume 19, pp. 205-234.

67. Aouissi, J.; Benabdallah, S.; Chabaane, Z.L.; Cudennec, C. Evaluation of potential evapotranspiration assessment methods for hydrological modelling with SWAT-Application in data-scarce rural Tunisia. Agric. Water Manag. 2016, 174, 39-51. [CrossRef]

68. Arnold, J.G.; Moriasi, D.N.; Gassman, P.W.; Abbaspour, K.C.; White, M.J.; Srinivasan, R.; Santhi, C.; Harmel, R.; Van Griensven, A.; Van Liew, M.W.; et al. SWAT: Model use, calibration, and validation. Trans. ASABE 2012, 55, 1491-1508. [CrossRef]

69. Abbaspour, K.C.; Vaghefi, S.A.; Srinivasan, R. A Guideline for Successful Calibration and Uncertainty Analysis for Soil and Water Assessment: A Review of Papers from the 2016 International SWAT Conference. Water 2017, 10, 6, [CrossRef]

70. Gupta, H.V.; Kling, H.; Yilmaz, K.K.; Martinez, G.F. Decomposition of the mean squared error and NSE performance criteria: Implications for improving hydrological modelling. J. Hydrol. 2009, 377, 80-91, [CrossRef]

71. Chilkoti, V.; Bolisetti, T.; Balachandar, R. Multi-objective autocalibration of SWAT model for improved low flow performance for a small snowfed catchment. Hydrol. Sci. J. 2018, 63, 1482-1501, [CrossRef]

72. Saraiva, A.M.; Masih, I.; Uhlenbrook, S.; Jewitt, G.P.; Van der Zaag, P. Improved process representation in the simulation of the hydrology of a meso-scale semi-arid catchment. Water 2018, 10, 1549. [CrossRef]

73. Siderius, C.; Biemans, H.; Kashaigili, J.J.; Conway, D. Going local: Evaluating and regionalizing a global hydrological model's simulation of river flows in a medium-sized East African basin. J. Hydrol. Reg. Stud. 2018, 19, 349-364. [CrossRef]

74. Zambrano-Bigiarini, M. hydroGOF: Goodness-of-Fit Functions for Comparison of Simulated and Observed Hydrological Time Series R Package Version 0.4-0. 2020. Available online: https:/ / cran.r-project.org/web/ packages/hydroGOF/hydroGOF.pdf (accessed on 4 May 2020).

75. Confesor, R.B.; Whittaker, G. Multi-Objective Automatic Calibration of a Semi-Distributed Watershed Model using Pareto Ordering Optimization and Genetic Algorithm. In Proceedings of the 2006 ASAE Annual Meeting. American Society of Agricultural and Biological Engineers, Portland, OR, USA, 9-12 July 2006; p. 1.

76. Zhang, Z.; Wagener, T.; Reed, P.; Bhushan, R. Reducing uncertainty in predictions in ungauged basins by combining hydrologic indices regionalization and multiobjective optimization. Water Resour. Res. 2008. [CrossRef] 
77. Ercan, M.B.; Goodall, J.L. Design and implementation of a general software library for using NSGA-II with SWAT for multi-objective model calibration. Environ. Model. Softw. 2016, 84, 112-120, [CrossRef]

78. Ching-Shih Tsou. nsga2R: Elitist Non-dominated Sorting Genetic Algorithm Based on R. 2013. Available online: https: / / cran.r-project.org/web/packages/nsga2R/nsga2R.pdf (accessed on 25 May 2020).

79. Hannah, D.M.; Kansakar, S.R.; Gerrard, A.; Rees, G. Flow regimes of Himalayan rivers of Nepal: nature and spatial patterns. J. Hydrol. 2005, 308, 18-32. [CrossRef]

80. Ward, J.H. Hierarchical grouping to optimize an objective function. J. Am. Stat. Assoc. 1963, 58, $236-244$. [CrossRef]

81. Jolliffe, I.T.; Cadima, J. Principal component analysis: A review and recent developments. Philos. Trans. R. Soc. Math. Phys. Eng. Sci. 2016, 374, 20150202. [CrossRef]

82. Rao, A.R.; Srinivas, V. Regionalization of watersheds by hybrid-cluster analysis. J. Hydrol. 2006, 318, 37-56. [CrossRef]

83. Liu, Y.; Li, Z.; Xiong, H.; Gao, X.; Wu, J. Understanding of internal clustering validation measures. In Proceedings of the 2010 IEEE International Conference on Data Mining, ICDM; IEEE: New York, NY, USA, 2010; pp. 911-916, [CrossRef]

84. Chavoshi, S.; Azmin Sulaiman, W.; Saghafian, B.; Sulaiman, M.N.; Latifah, A. Soft and hard clustering methods for delineation of hydrological homogeneous regions in the southern strip of the Caspian Sea W atershed. J. Flood Risk Manag. 2012, 5, 282-294. [CrossRef]

85. Brock, G.; Pihur, V.; Datta, S.; Datta, S.; Brock, M.G.; Biobase, S. clValid, an R package for cluster validation. J. Stat. Softw., 2020, 25, 1-22.

86. Xie, Z.; Yuan, F.; Duan, Q.; Zheng, J.; Liang, M.; Chen, F. Regional Parameter Estimation of the VIC Land Surface Model: Methodology and Application to River Basins in China. J. Hydrometeorol. 2007, 8, 447-468, [CrossRef]

87. Efron, B. Bootstrap methods: Another look at the jackknife. In Breakthroughs in Statistics; Springer: New York, NY, USA, 1992; pp. 569-593.

88. Bourgin, F.; Andréassian, V.; Perrin, C.; Oudin, L. Transferring global uncertainty estimates from gauged to ungauged catchments. Hydrol. Earth Syst. Sci. 2015, 19, 2535-2546, [CrossRef]

89. Bock, A.R.; Farmer, W.H.; Hay, L.E. Quantifying uncertainty in simulated streamflow and runoff from a continental-scale monthly water balance model. Adv. Water Resour. 2018, 122, 166-175, [CrossRef]

90. Levin, S.; Farmer, W. Evaluation of Uncertainty Intervals for Daily, Statistically Derived Streamflow Estimates at Ungaged Basins Across the Continental U.S. Water 2020, 12, 1390, [CrossRef]

91. Milliman, J.D.; Farnsworth, K.L. River Discharge to the Coastal Ocean: A Global Synthesis; Cambridge University Press: Cambridge, UK, 2013.

92. Falkenmark, M.; Rockström, J. The new blue and green water paradigm: Breaking new ground for water resources planning and management. J. Water Resour. Plan. Manag. 2006, 132, 129-132. [CrossRef]

93. Reichl, J.; Western, A.; McIntyre, N.; Chiew, F. Optimization of a similarity measure for estimating ungauged streamflow. Water Resour. Res. 2009, 45.:10.1029/2008WR007248. [CrossRef]

94. Merz, R.; Blöschl, G. Flood frequency regionalisation—spatial proximity vs. catchment attributes. J. Hydrol. 2005, 302, 283-306. [CrossRef]

95. Merz, R.; Blöschl, G.; Parajka, J. Spatio-temporal variability of event runoff coefficients. J. Hydrol. 2006, 331, 591-604. [CrossRef]

96. Sood, A.; Muthuwatta, L.; McCartney, M. A SWAT evaluation of the effect of climate change on the hydrology of the Volta River basin. Water Int. 2013, 38, 297-311, [CrossRef]

97. Chu, T.; Shirmohammadi, A. Evaluation of the SWAT model's hydrology component in the piedmont physiographic region of Maryland. Trans. ASAE 2004, 47, 1057. [CrossRef]

98. Pfannerstill, M.; Guse, B.; Fohrer, N. A multi-storage groundwater concept for the SWAT model to emphasize nonlinear groundwater dynamics in lowland catchments. Hydrol. Process. 2014, 28, 5599-5612. [CrossRef]

99. Luo, Y.; Arnold, J.; Allen, P.; Chen, X. Hydrology and Earth System Sciences Baseflow simulation using SWAT model in an inland river basin in Tianshan Mountains, Northwest China. Hydrol. Earth Syst. Sci. 2012, 16, 1259-1267, [CrossRef]

100. Izady, A.; Davary, K.; Alizadeh, A.; Ziaei, A.N.; Akhavan, S.; Alipoor, A.; Joodavi, A.; Brusseau, M.L. Conceptualisation et modélisation hydrogéologique de la plain semi-aride et agricole de Neishaboor (Iran) en utilisant le modèle distribué SWAT. Hydrogeol. J. 2014, 23, 47-68, [CrossRef] 
101. Dowlatabadi, S.; Ali Zomorodian, S.M. Conjunctive simulation of surface water and groundwater using SWAT and MODFLOW in Firoozabad watershed. KSCE J. Civ. Eng. 2016, 20, 485-496, [CrossRef]

102. Shao, G.; Zhang, D.; Guan, Y.; Xie, Y.; Huang, F. Application of SWAT model with a modified groundwater module to the semi-arid Hailiutu River catchment, northwest China. Sustainability 2019, 11, 2031, [CrossRef]

Publisher's Note: MDPI stays neutral with regard to jurisdictional claims in published maps and institutional affiliations.

(C) 2020 by the authors. Licensee MDPI, Basel, Switzerland. This article is an open access article distributed under the terms and conditions of the Creative Commons Attribution (CC BY) license (http:/ / creativecommons.org/licenses/by/4.0/). 